\title{
The macromolluscs of Mermaid (Rowley Shoals), Scott and Seringapatam Reefs, Western Australia.
}

\author{
Clay Bryce and Corey Whisson \\ Department of Aquatic Zoology \\ Mollusc Section, Department of Aquatic Zoology, Western Australian Museum, \\ Locked Bag 49, Welshpool DC, WA 6986, Australia. \\ Email: Clay.Bryce@museum.wa.gov.au,Corey.Whisson@museum.wa.gov.au
}

\begin{abstract}
This paper records 339 macromolluscan species comprising 261 gastropods, 70 bivalves, six cephalopods and two chiton species from the north-western Australian atolls of Mermaid Reef (Rowley Shoals), Scott and Seringapatam Reefs.

These records result from a survey undertaken by the WA Museum in September 2006, during which both qualitative and quantitative data sets were recorded. The data included a comprehensive inventory of molluscs, based on a presence/absence statistical assessment, and quantitative density records along replicated transects at outer slope and lagoonal stations. The qualitative survey results are compared with those from WA Museum surveys to the Rowley Shoals in 1982 and Scott and Seringapatam reefs in 1984, as well as from other locations of regional significance. While Mermaid Reef appeared little affected, habitat changes were apparent on Scott and Seringapatam Reefs. The shifts in some molluscan populations since the surveys in the 1980s may be related to warm water incursions, cyclonic activity and/or unregulated fishing. The populations of three gastropod species, Cerithium echinatum, Conus miliaris and Conus musicus, appeared to have increased, probably due to habitat change, when compared to data from the 1980s. However, the populations of giant clams (Tridacna spp. and Hippopus hippopus) and trochus (Tectus niloticus) on Scott and Seringapatam reefs had significantly declined, probably with the added pressure of unregulated fishing. These latter declines are supported by the findings of the senior author during a separate survey concerning a survey of the invertebrate marine resources of Scott Reef, Seringapatam Reef and Browse Island in February, 2006 (Bryce, 2006). A new Australian record for Marchia martinetana (Röding,1798) (Muricidae), is documented from North Scott Reef, and three new Western Australian records, for Euplica deshayesii (Crosse,1859) (Columbellidae), Notodoris serenae Gosliner and Behrens, 1997 (Aegiridae) and Monitilora simplex (Reeve,1850) (Lucinidae) are also documented. The records of Pitar spoori Lamprell and Whitehead, 1990 (Veneridae) is also significant as that species has only previously been recorded from Hibernia Reef, off north-western Australia.
\end{abstract}

\section{INTRODUCTION}

The Western Australian Museum (WA Museum) has now undertaken three marine macromolluscan surveys of oceanic, shelf-edge atolls off the North West Shelf of northwestern Australia. The first was to the Rowley Shoals, visiting Clerke and Mermaid Reefs in 1982, the second to North and South Scott Reefs and Seringapatam Reef in 1984 - the results for these two surveys being published in 1986 (Wells and Slack-Smith in Berry, 1986). A third survey to Ashmore Reef and Cartier Island was completed in 1986 (Wells in Berry, 1993).

This paper inventories the macromolluscs (Table 1) recorded during a WA Museum marine biodiversity survey undertaken in September 2006 at Mermaid Reef (Rowley Shoals), North and South Scott Reefs and Seringapatam Reef. Comparisons are made with the results from the WA Museum's 1986 report.

Since 1986 several surveys of the offshore reefs and atolls of that region have also been carried out by the Australian Commonwealth Scientific and Industrial Research Organisation (CSIRO) (Skewes, 1999a, 1999b) and the Australian Institute of Marine Sciences (AIMS) (Rees, 2003; Smith, 2005). The aim of those surveys was to examine the marine resources of the reefs, including species of giant clams belonging to the genera Tridacna and Hippopus, and the trochid gastropod, 


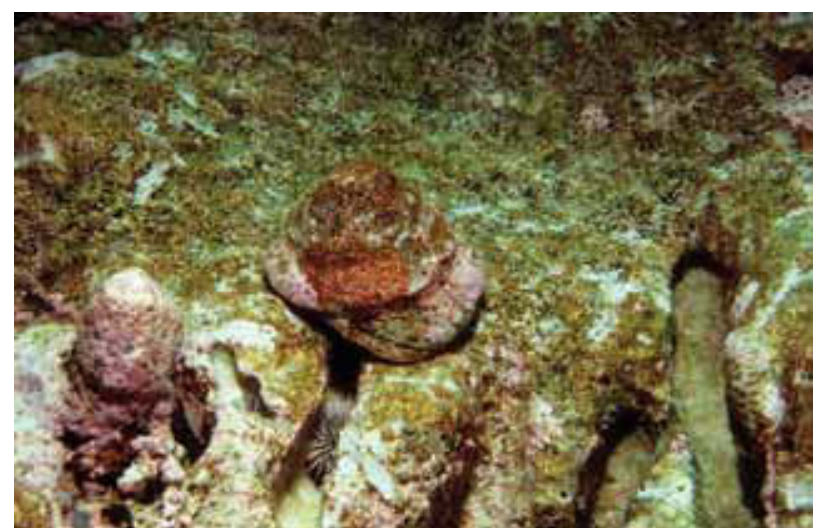

Above: Tectus niloticus Linnaeus, 1767. Species numbers were very poor due to unsustainable fishing practices. (Photo: Clay Bryce)

Tectus niloticus. In February 2006 the senior author surveyed the marine invertebrate resource species of holothurians, giant clams and trochus of Scott Reef, Seringapatam Reef and Browse Island (Bryce, 2006).

\section{METHODOLOGY}

Only macromolluscan species are included in this report. Macromolluscs are defined as species with adult size greater than or equal to one centimetre. Only those species taken/recorded during this survey are included. Data from molluscan collections, recorded over time during collecting trips by this and other museums, have not been included.

The previous molluscan surveys undertaken in 1982 and 1984 were qualitative in nature and recorded observed species at each station. The methodology adopted for this 2006 survey incorporated both qualitative and quantitative aspects. The former recorded species presence at all stations while the latter recorded the density of molluscs along replicated transects for lagoon and outer reef slope stations. Intertidal reef platform (intertidal platform) and channel stations were not sampled quantitatively. All stations were sampled over one hour and during daylight hours for logistical and safety reasons.

\section{Transect stations: Outer Reef slope and lagoonal stations.}

Replicate transects (each one metre wide and five metres apart) were established at outer slope and lagoonal stations. Transects were searched by two divers who recorded the presence and abundance of molluscan species. However, species from the families Vermetidae and Hipponicidae were not counted because of time constraints.

Transects ran from the deepest (maximum of $20 \mathrm{~m}$ ) to the shallowest points of each station and followed a preset compass bearing. While this provided the greatest degree of habitat change it also resulted in transects of differing lengths. To compensate, molluscan density data were standardised to $50 \mathrm{~m}^{2}$.

Because of the hidden nature of most molluscs, rocks and coral slabs, when abundant, were turned at five metre depth intervals along the transects. Where the rocks and slabs on the transects were few, all were turned and investigated. Small, scattered sand patches were raked for infaunal molluscan species and larger sand plains were subsampled by raking an area of $1 \mathrm{~m}^{2}$ at every alternate metre along the transect lines. Short handled rakes, $500 \mathrm{~cm}$ wide, which penetrated the substrate to a maximum depth of $5 \mathrm{~cm}$, were used for this purpose.

During the transect-swims, extra qualitative, off-transect searches were undertaken to increase the coverage of mollusc species recorded for the station. This was accomplished in two ways. Firstly, by the diver periodically halting his progress along the transect, marking his position and then exploring mollusc-rich habitats adjacent to that point on the transect. Secondly, by investigation of areas adjacent to the transects once the transectswim had been completed. This ensured that the molluscan fauna from all depths and habitats along and adjacent to the transects was surveyed within the allotted one hour dive time.

Progressing along each transect, each diver manually recorded the species and numbers of all macromolluscs encountered. Unidentified or noteworthy specimens were collected and later identified and retained as registered vouchers in the collections of the WA Museum.

This method proved efficient. By swimming the compass bearing, the time taken to lay and retrieve a transect-tape was saved. This time saving impacted favourably on maximising in-water

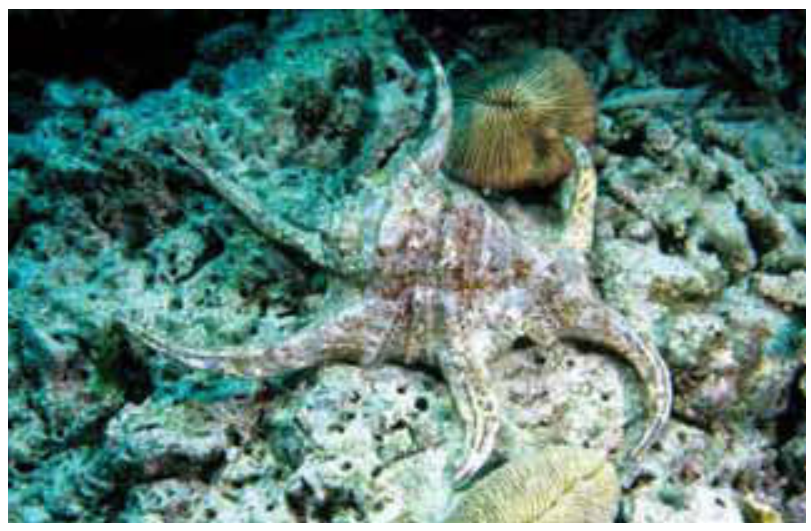

Above: Lambis chiragra (Linnaeus, 1758). A common reef species collected by fishers for the international shell trade. (Photo: Clay Bryce) 
data collecting time and limiting the overall diver nitrogen loads.

\section{Non-quantitative stations: Intertidal reef platform and channel drift stations.}

Intertidal platform stations presented a particular problem for recording molluscan densities. Effective sampling of the very wide intertidal reef platforms, often over one kilometre wide, was difficult within the workable period of a low tide cycle. Intertidal platform stations were treated as biodiversity sites and no attempt was made to quantify the species.

Faunal surveys of the stations in the channels, where excessive water flow precluded detailed searching, could be accomplished only by drift diving and so were also limited to qualitative assessments.

\section{HABITAT DIVISIONS}

References to habitats in this paper are double tiered. The first habitat tier describes the broadscale topographical features found on many atolls, such as the lagoon, intertidal reef platform and the outer reef slope. The second tier refers to those habitat divisions within each station that are relevant to molluscan biology and life history. Survey stations, particularly those around the outer reef slope and in the atoll lagoons, generally encompassed several intergrading habitats e.g. a subtidal coral reef merging through broken coral rubble with sandy pockets to an open sandy plain.

Second tier habitat divisions adopted here are:

\section{Intertidal Hard Substrate (IH):}

This is an intertidal zone consisting mainly of coral rubble and reef pavement. These hard substrates may be covered with a thin coating of

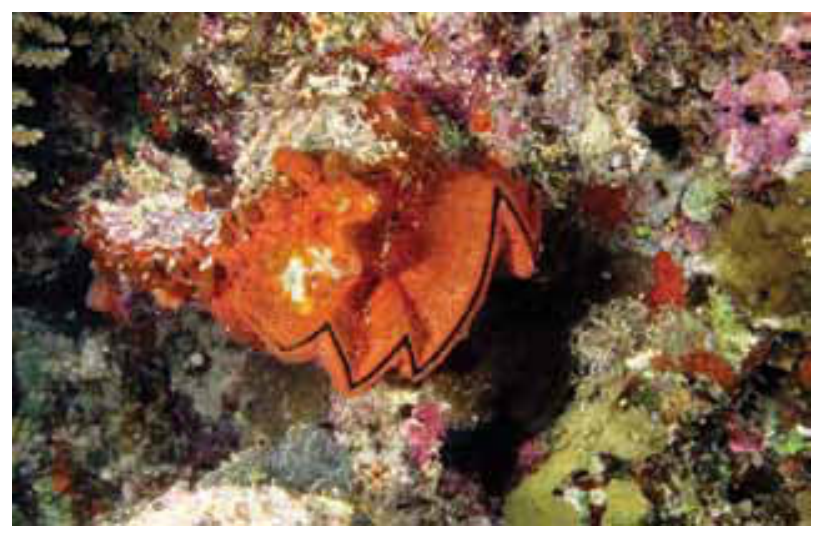

Above: Lopha cristigalli (Linnaeus, 1758). This species, with Hyotissa hyotis (Linnaeus, 1758) and Hyotissa numisma (Lamarck, 1819), had suffered severe population loss due to the destruction of coral habitat from a combination of coral bleaching and cyclonic activity. (Photo: Clay Bryce)

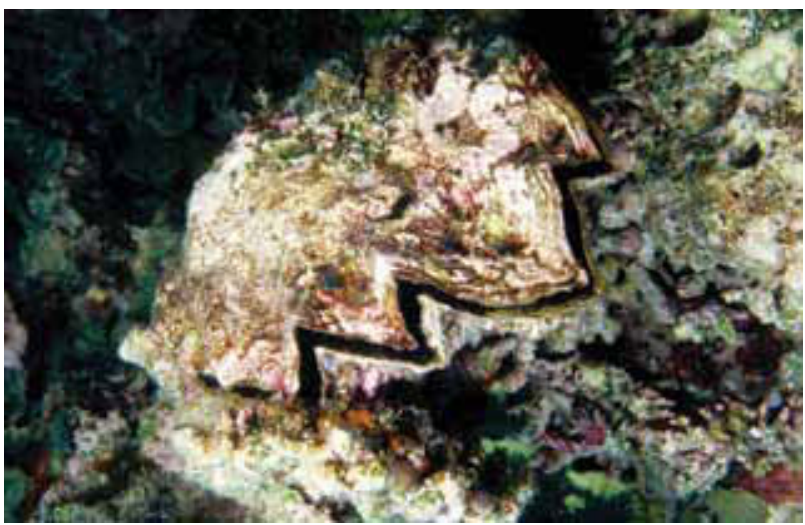

Above: Hyotissa hyotis (Linnaeus, 1758) (Photo: Clay Bryce)

sediment and algal turf.

Subtidal Hard Substrate (SH):

As above, but situated below low-tide level at outer slope and lagoon stations.

\section{Sediment (S):}

Intertidal and subtidal sand habitats. In such habitats, molluscan species may be infaunal or epifaunal.

\section{Pelagic (P):}

This habitat is represented by the water column from the sea surface to the substrate.

\section{Associated with another organism:}

This habitat type applies to those molluscs whose survival strategy involves an intimate and obligatory association with another life form.

\section{Epiphytic (EP):}

Plant-related associations, in which a species of seagrass or alga is the obligatory substrate

\section{Epizooic (EZ)}

Faunal related associations where an animal forms the obligatory substrate, such as coral, gorgonians and another species of $\mathrm{m}$ ollusc.

\section{RESULTS AND DISCUSSION:}

The molluscan species recorded during the 2006 survey are listed in Table 1 with WA Museum registration numbers being given for significant species. The taxonomic order adopted follows Beesley et al., 1998, with some subsequent taxonomic amendments. Station numbers, relevant habitat divisions and comparative records from the 1986 survey report (Wells and Slack-Smith 1986) are also included whether or not the species were recorded during this survey.

During the 1982 survey, 389 species were 


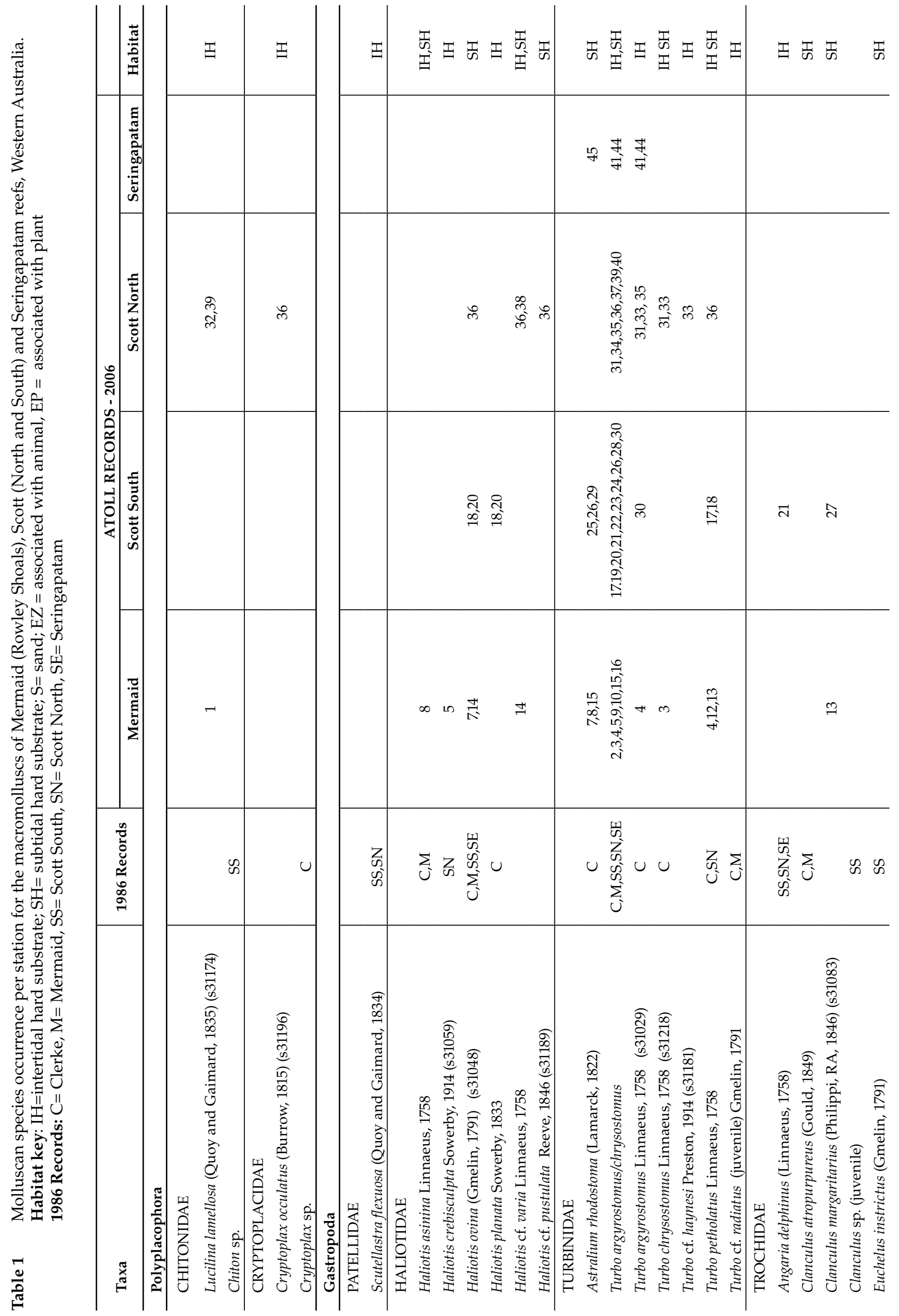




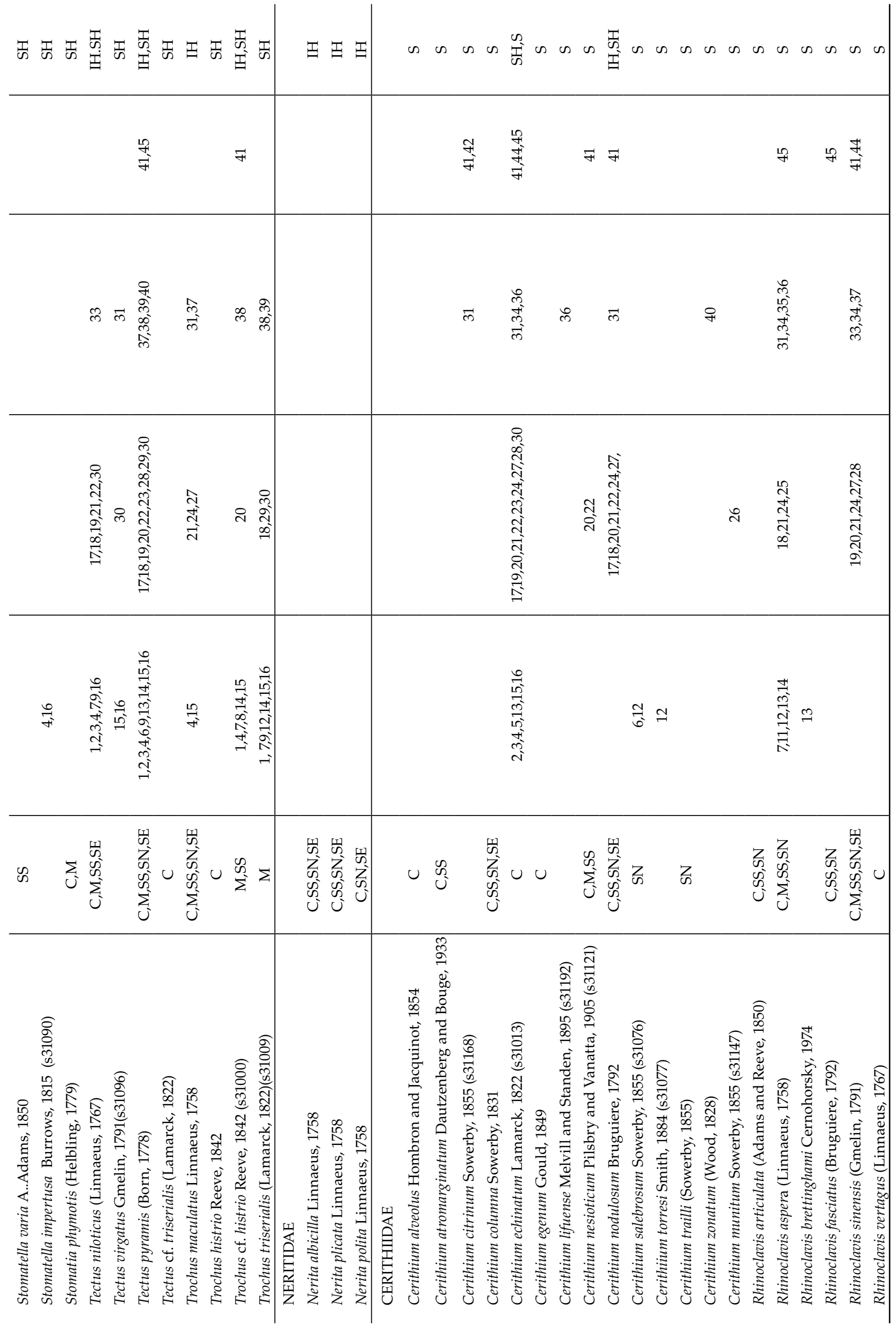




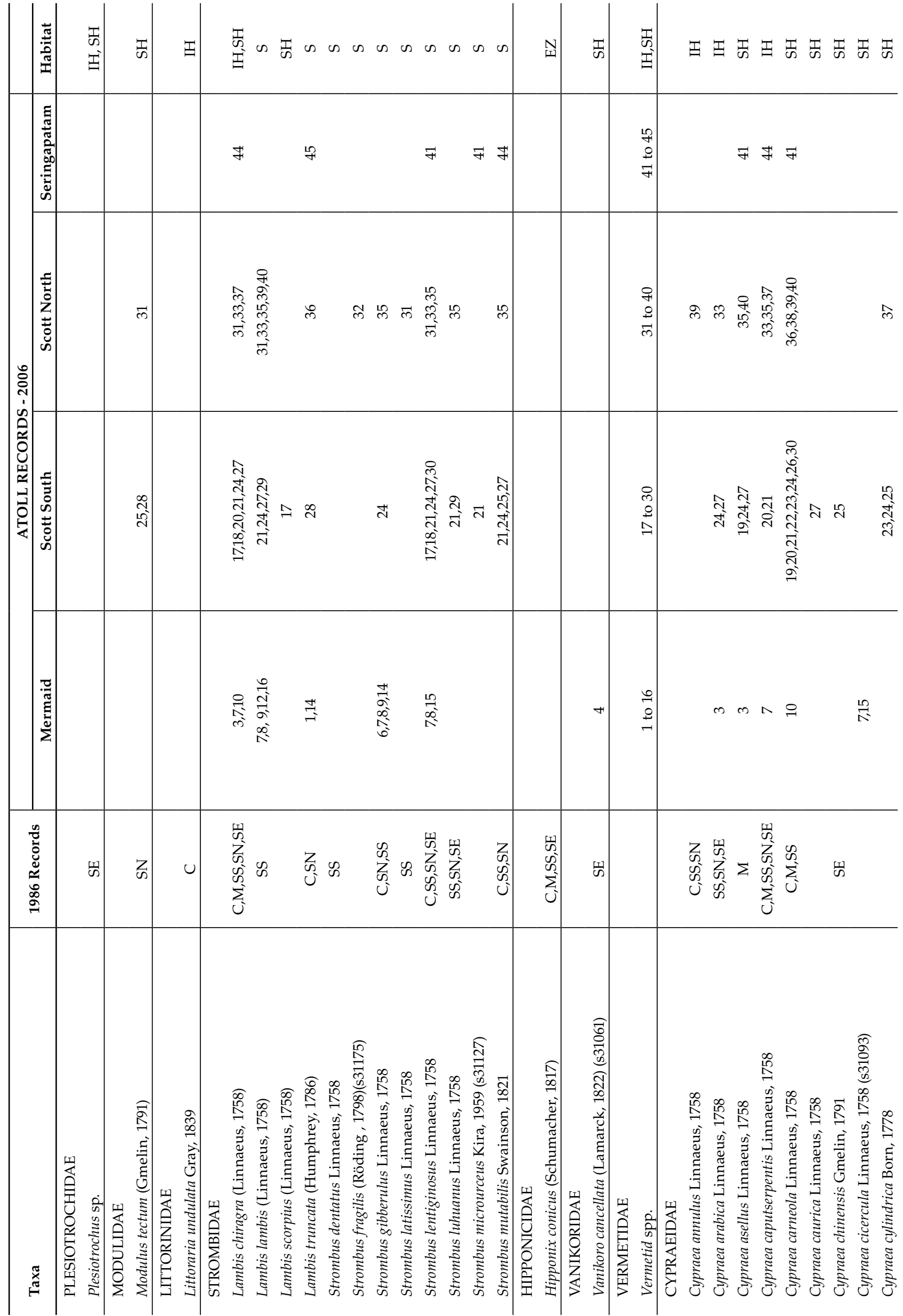




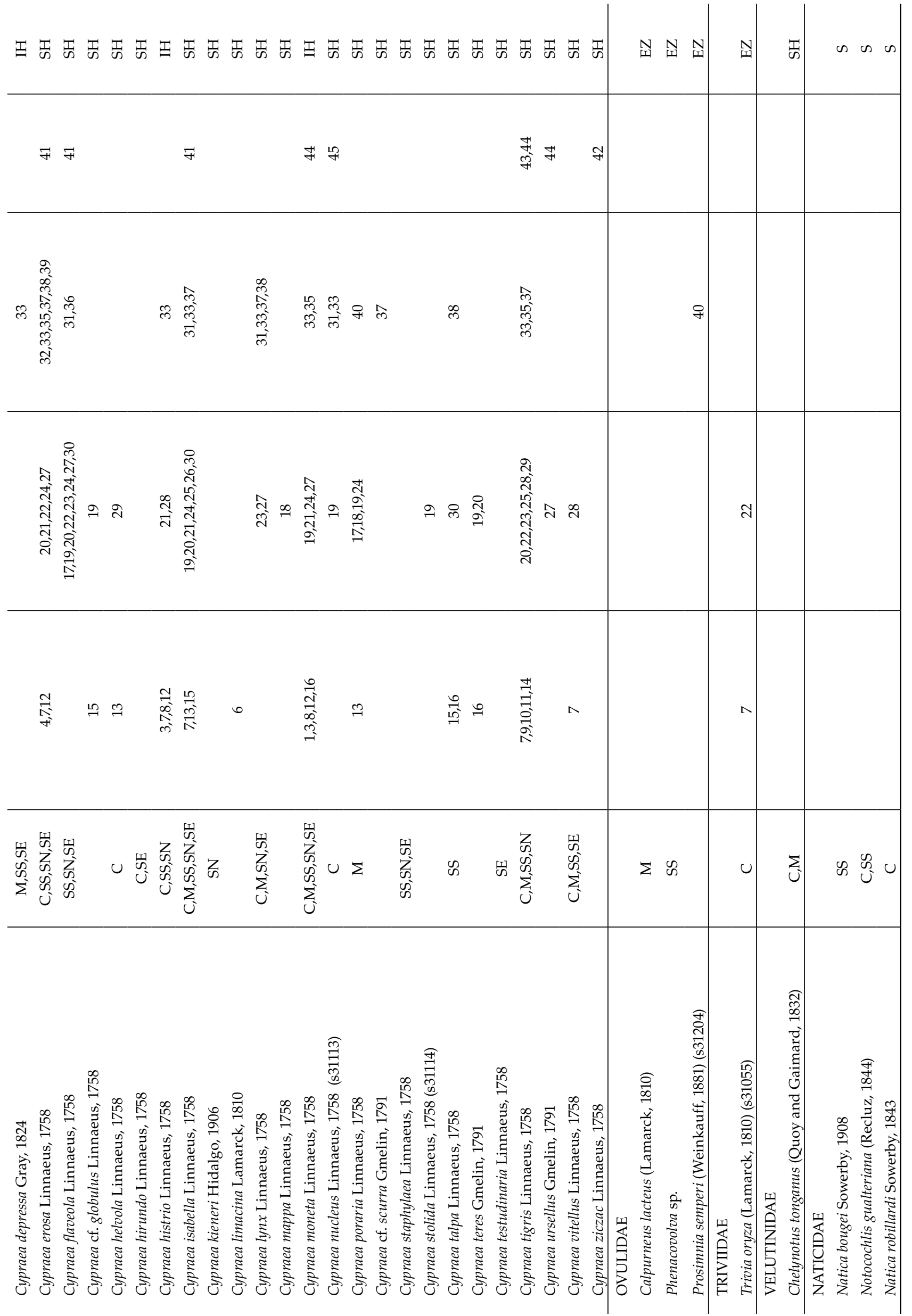




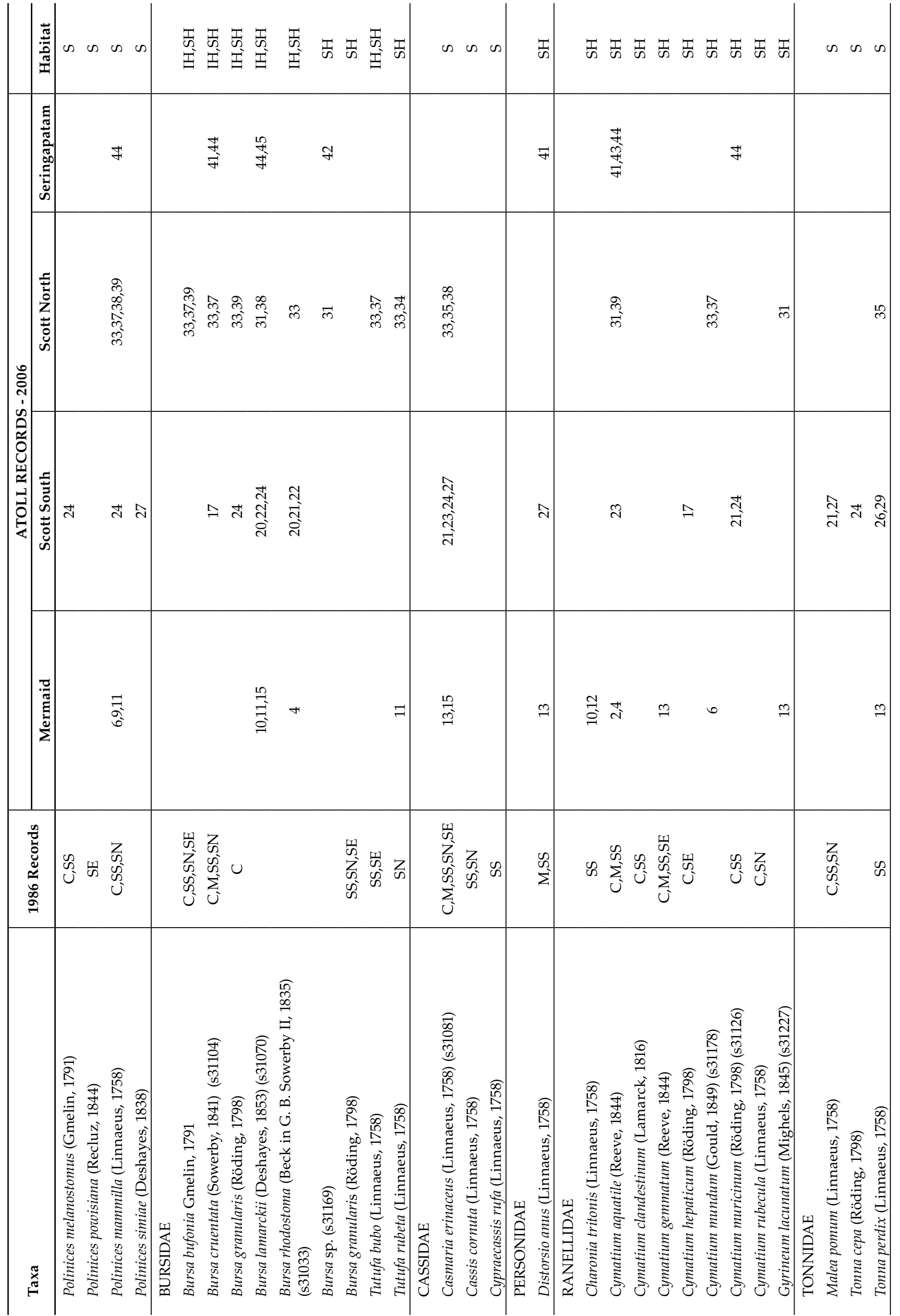




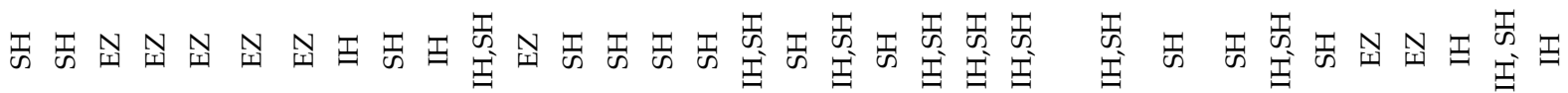

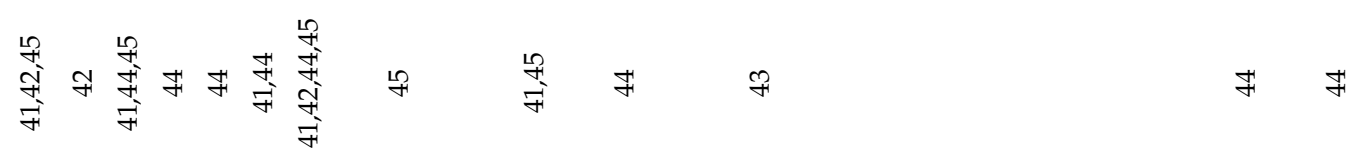

\begin{tabular}{|c|c|c|c|c|c|c|c|}
\hline 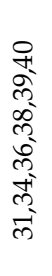 & 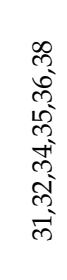 & 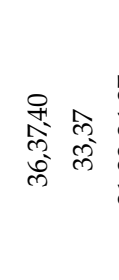 & 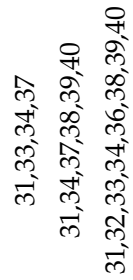 & "ా & $\begin{array}{c}\hat{m} \\
\tilde{n}^{\infty}\end{array}$ & $\begin{array}{l}\text { ले } \\
\infty^{\infty}\end{array}$ & $ल \approx$ \\
\hline
\end{tabular}

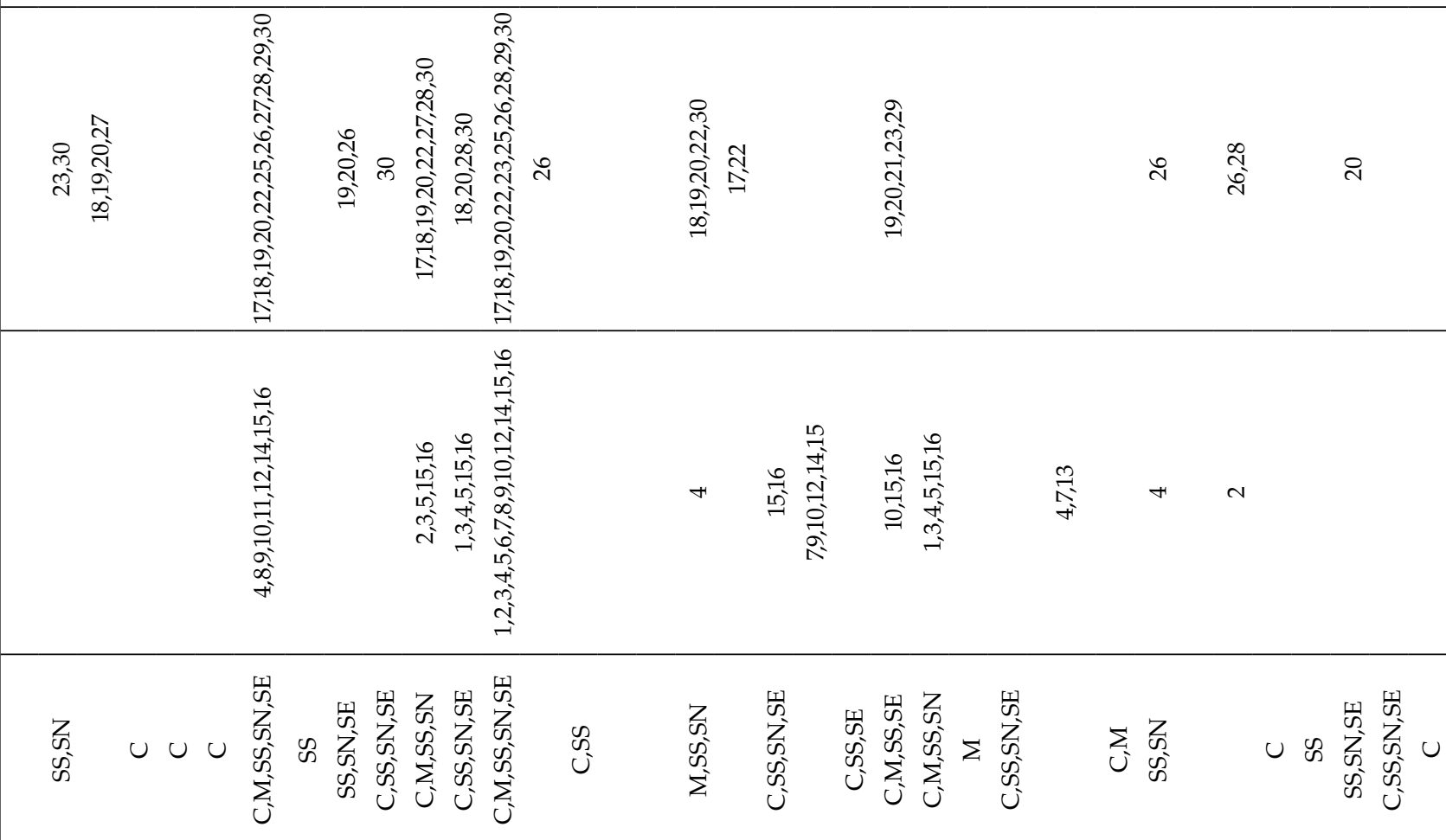




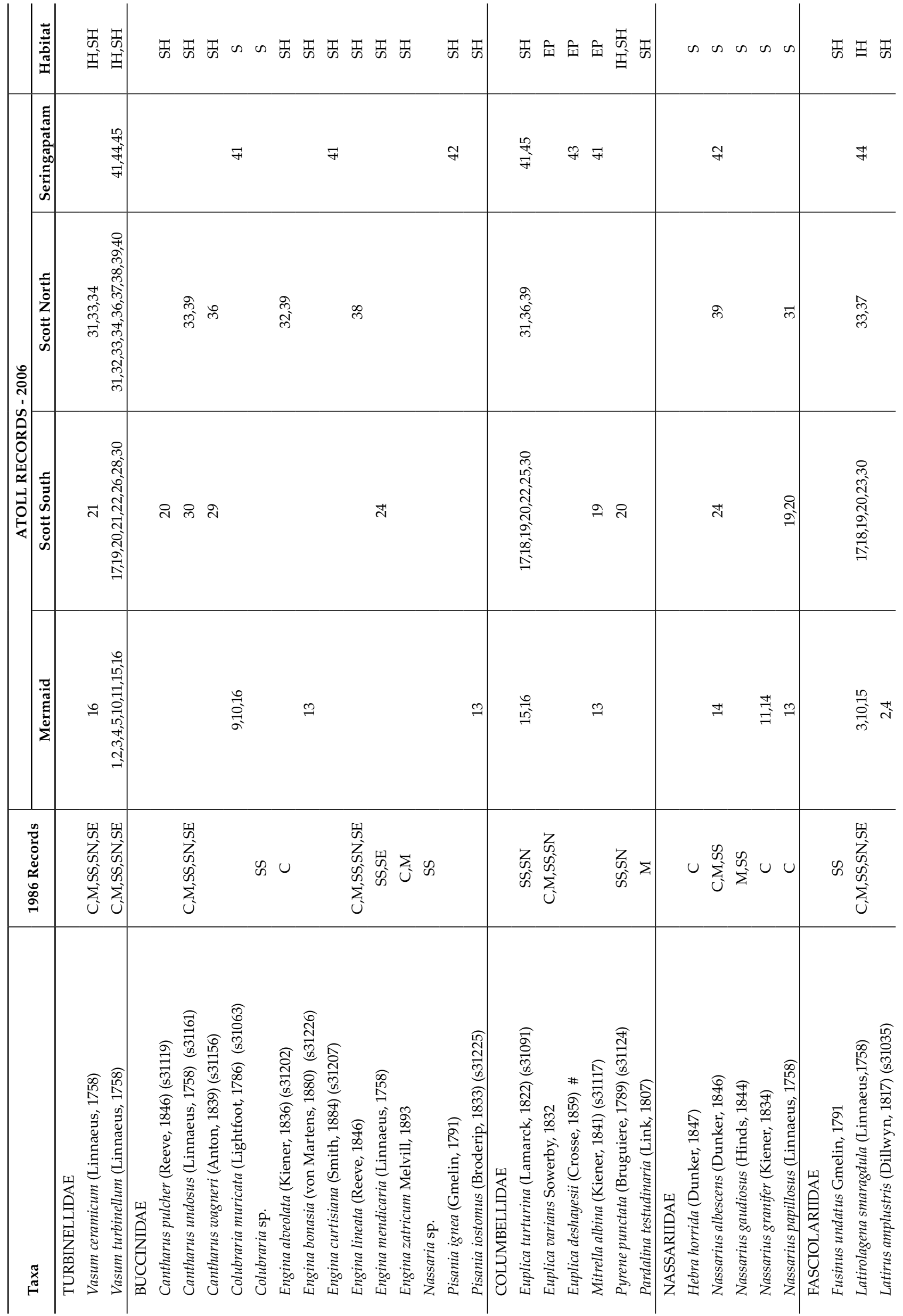




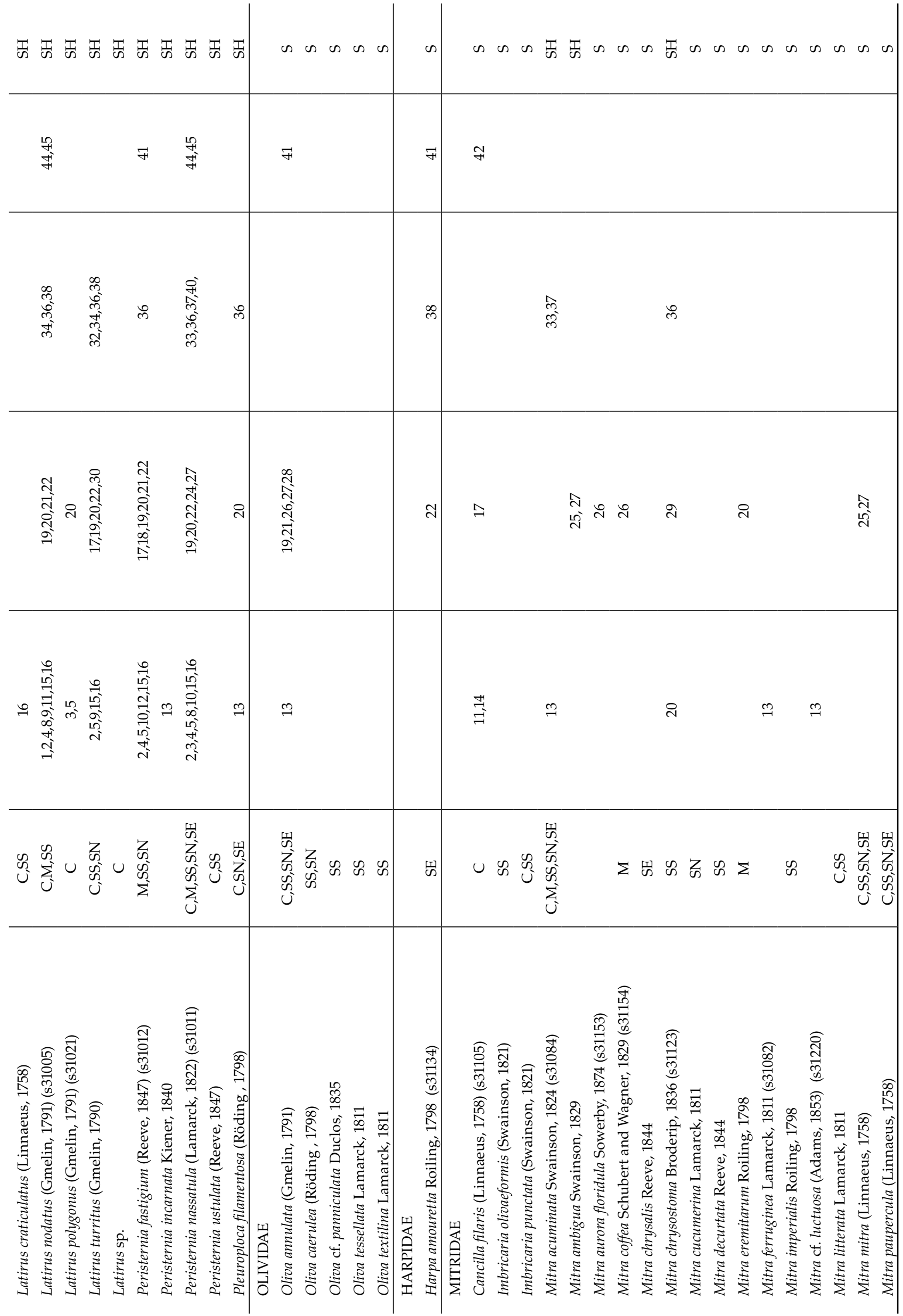




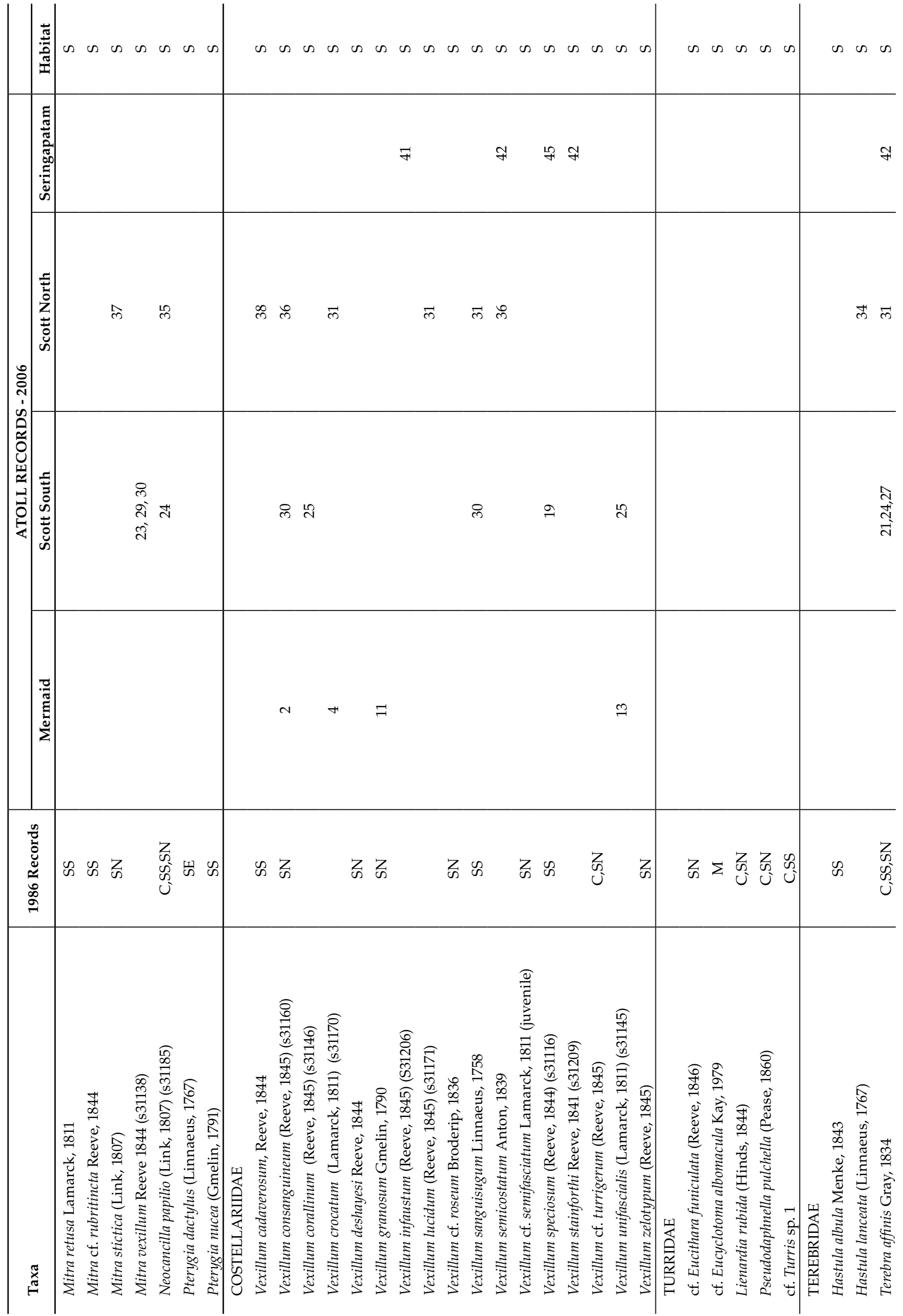




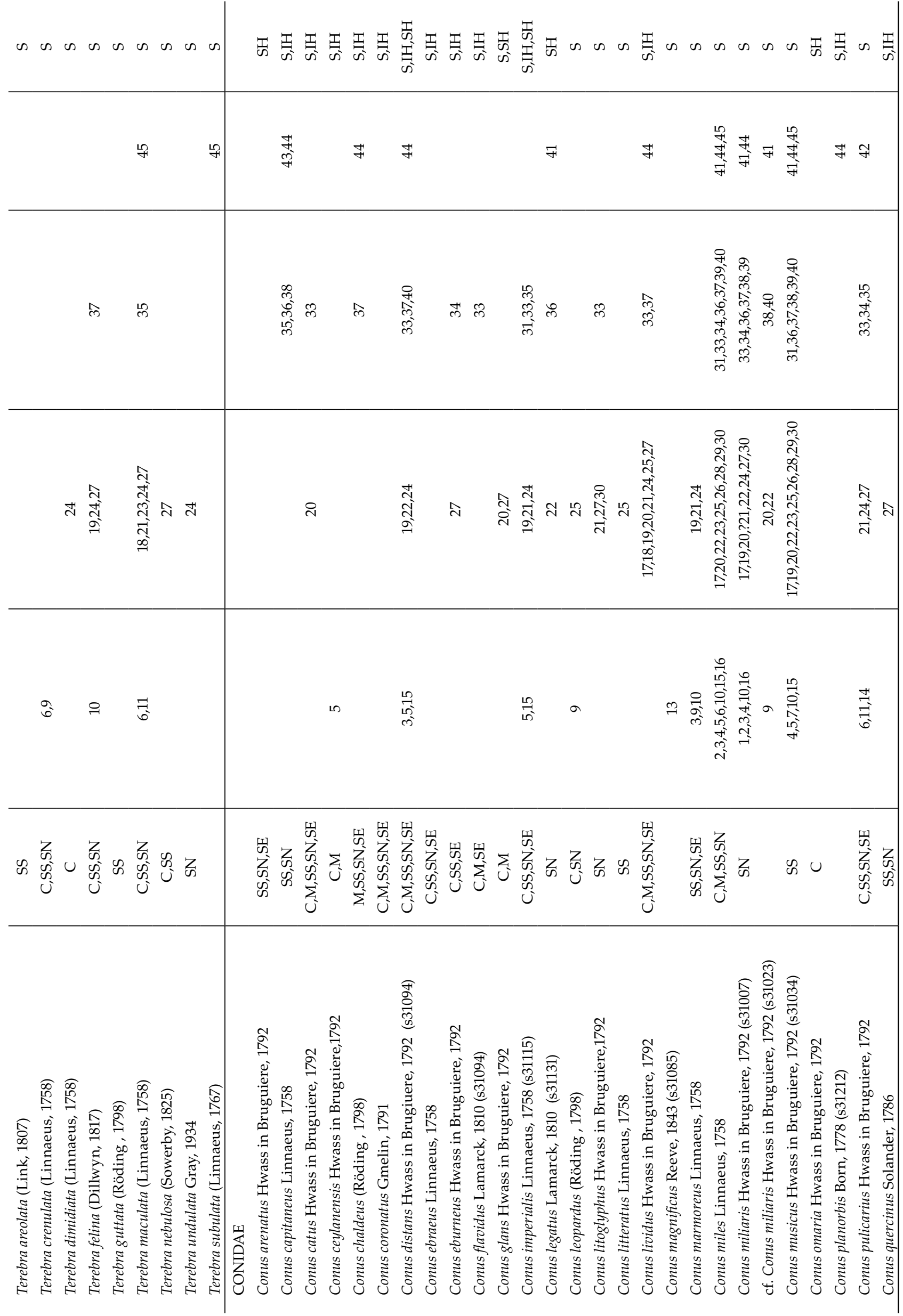




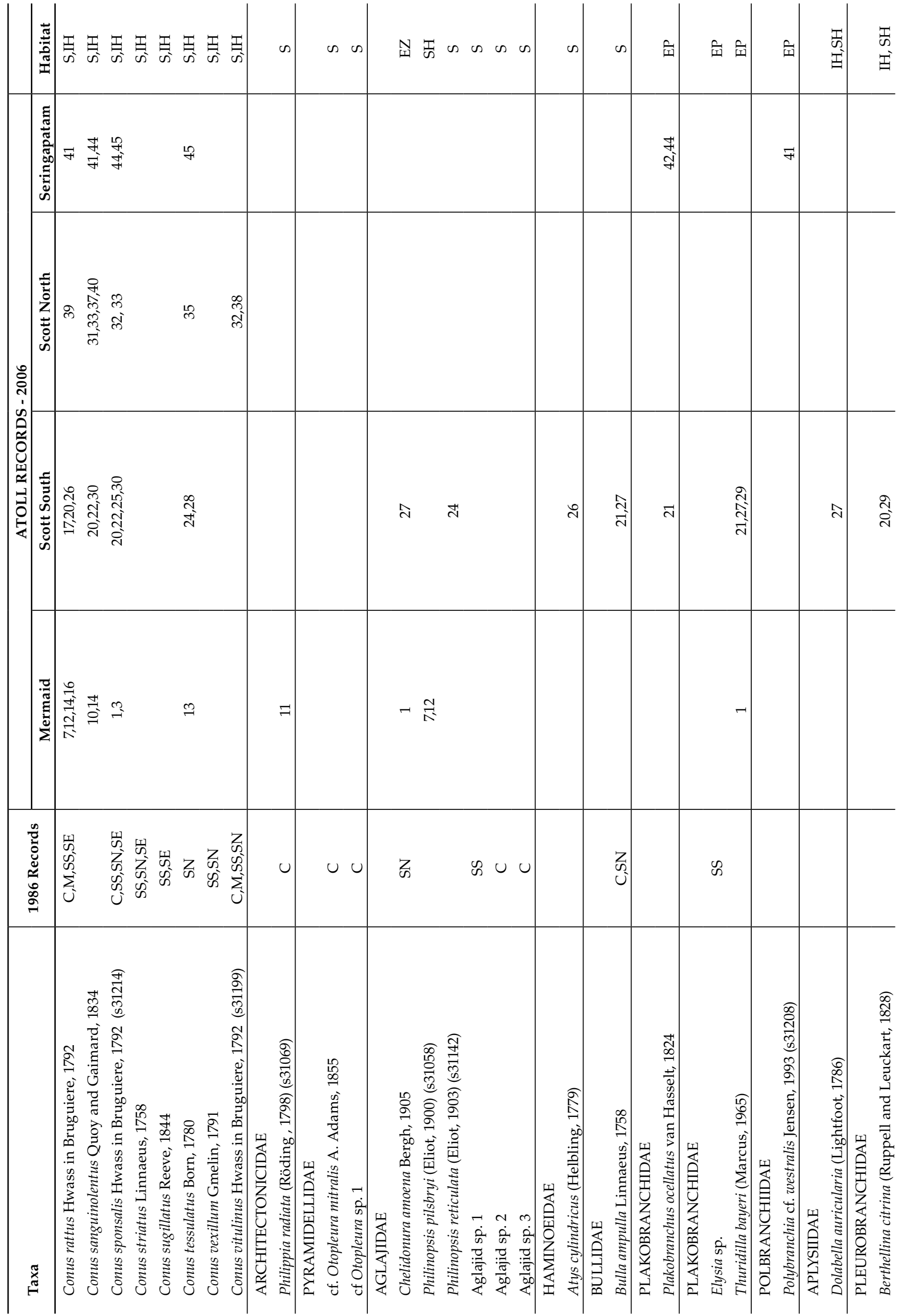




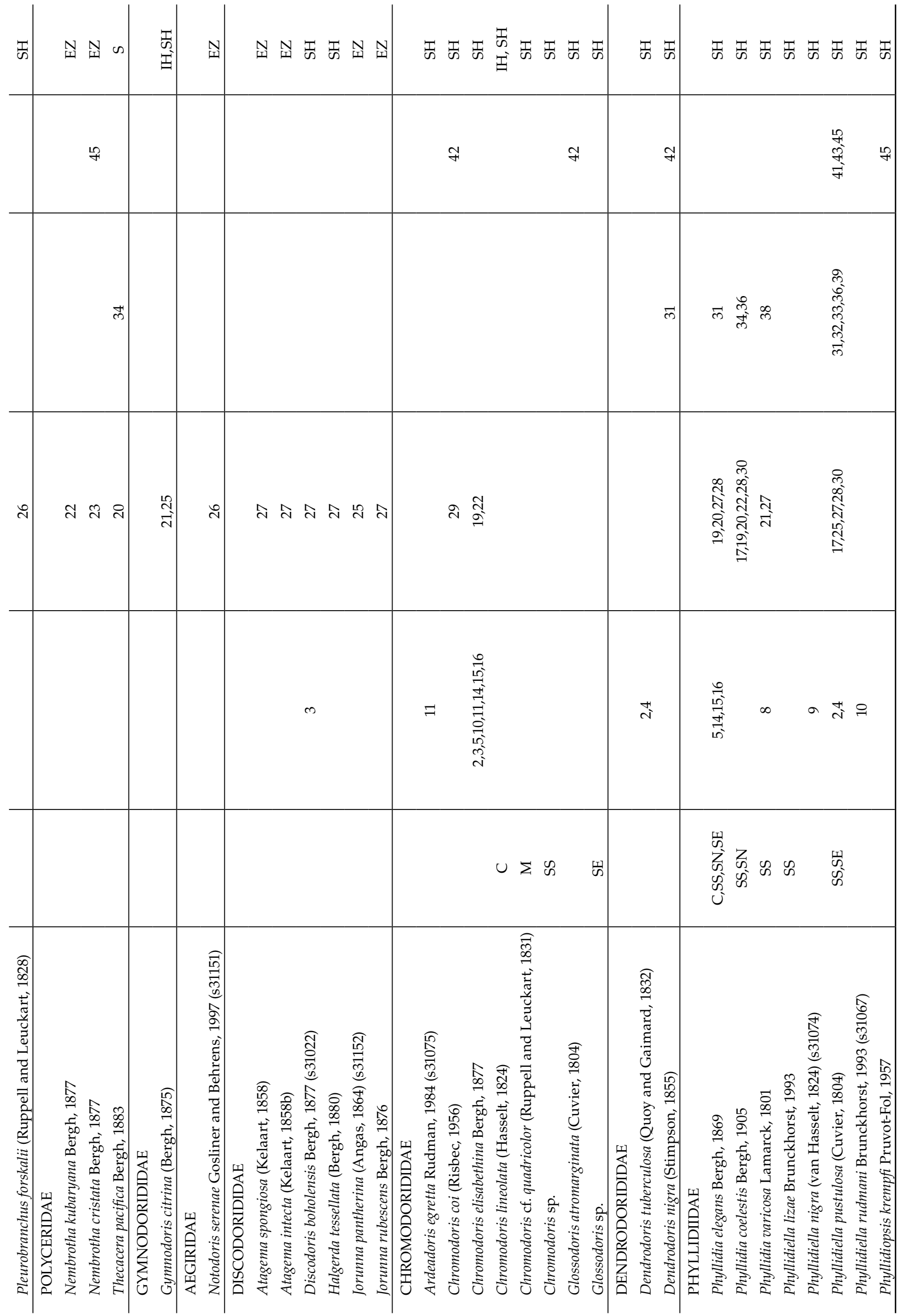




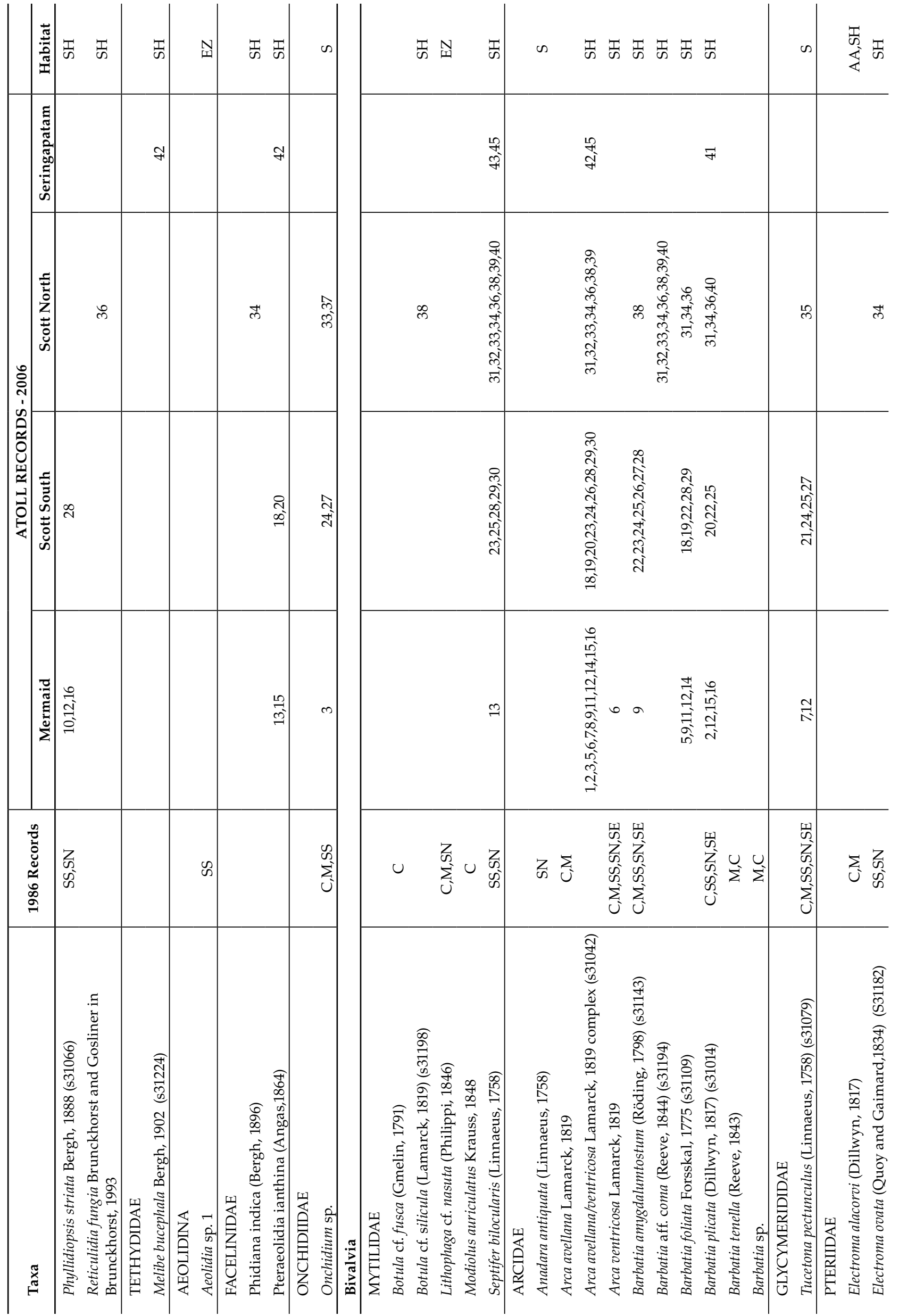




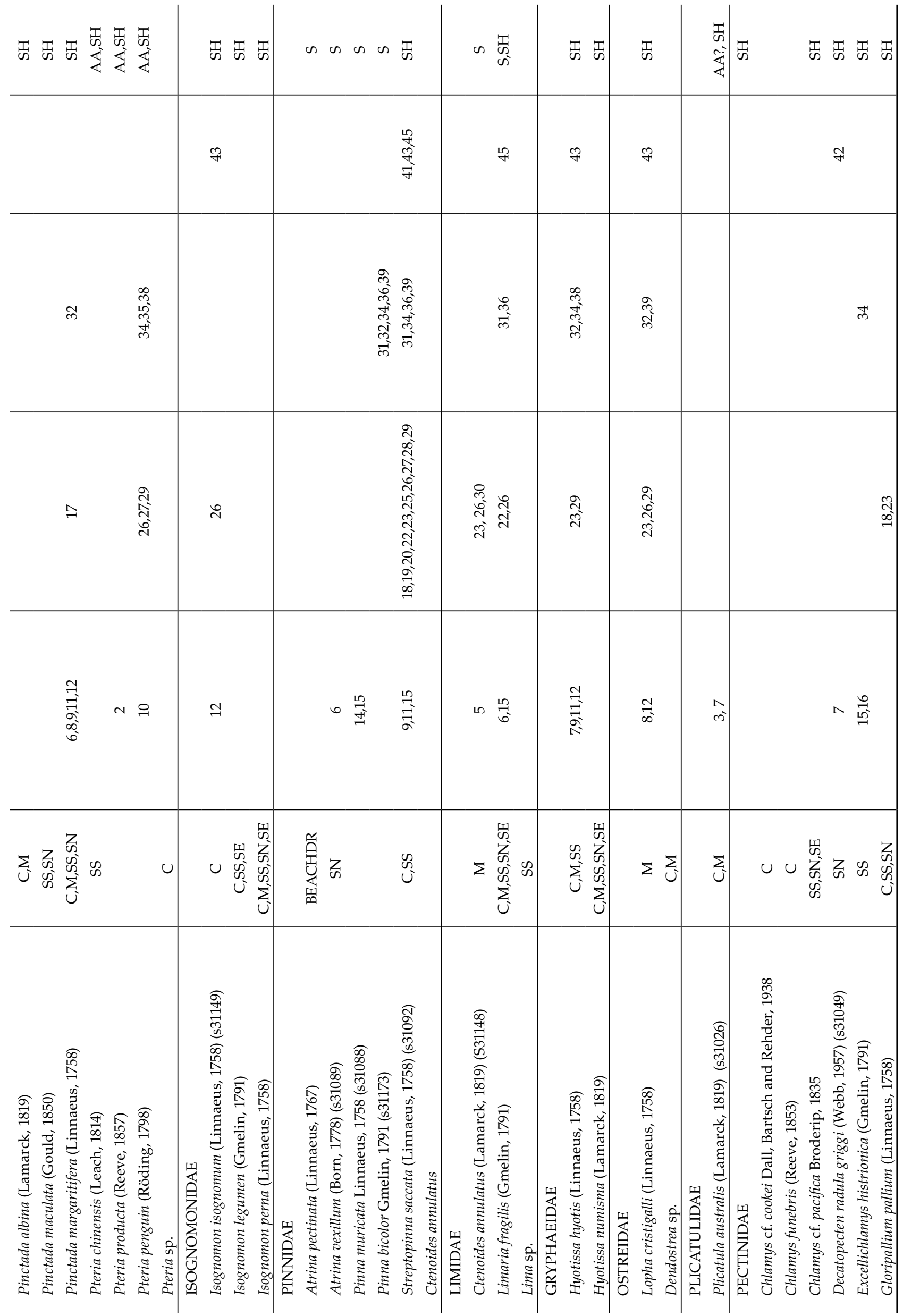




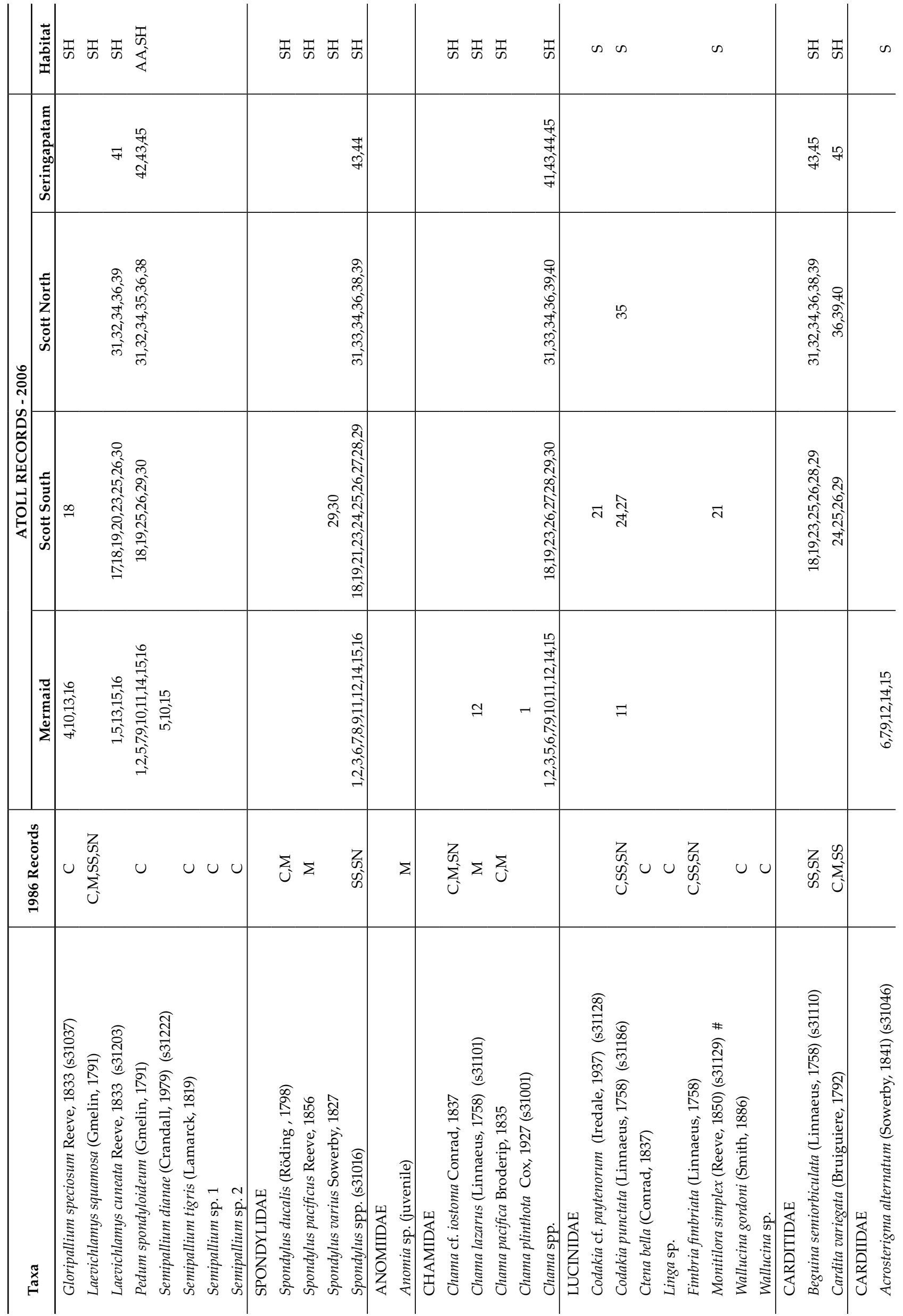




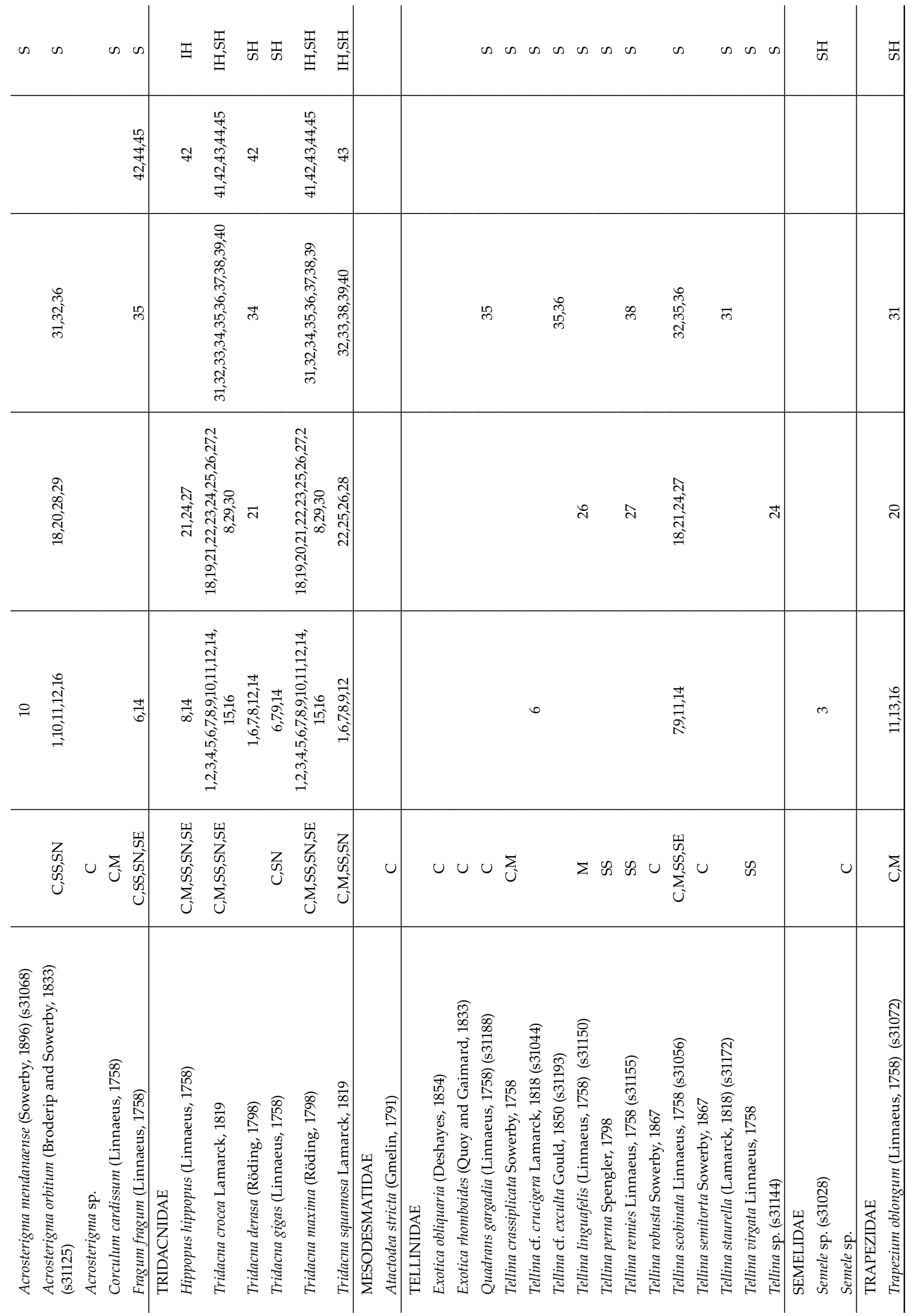




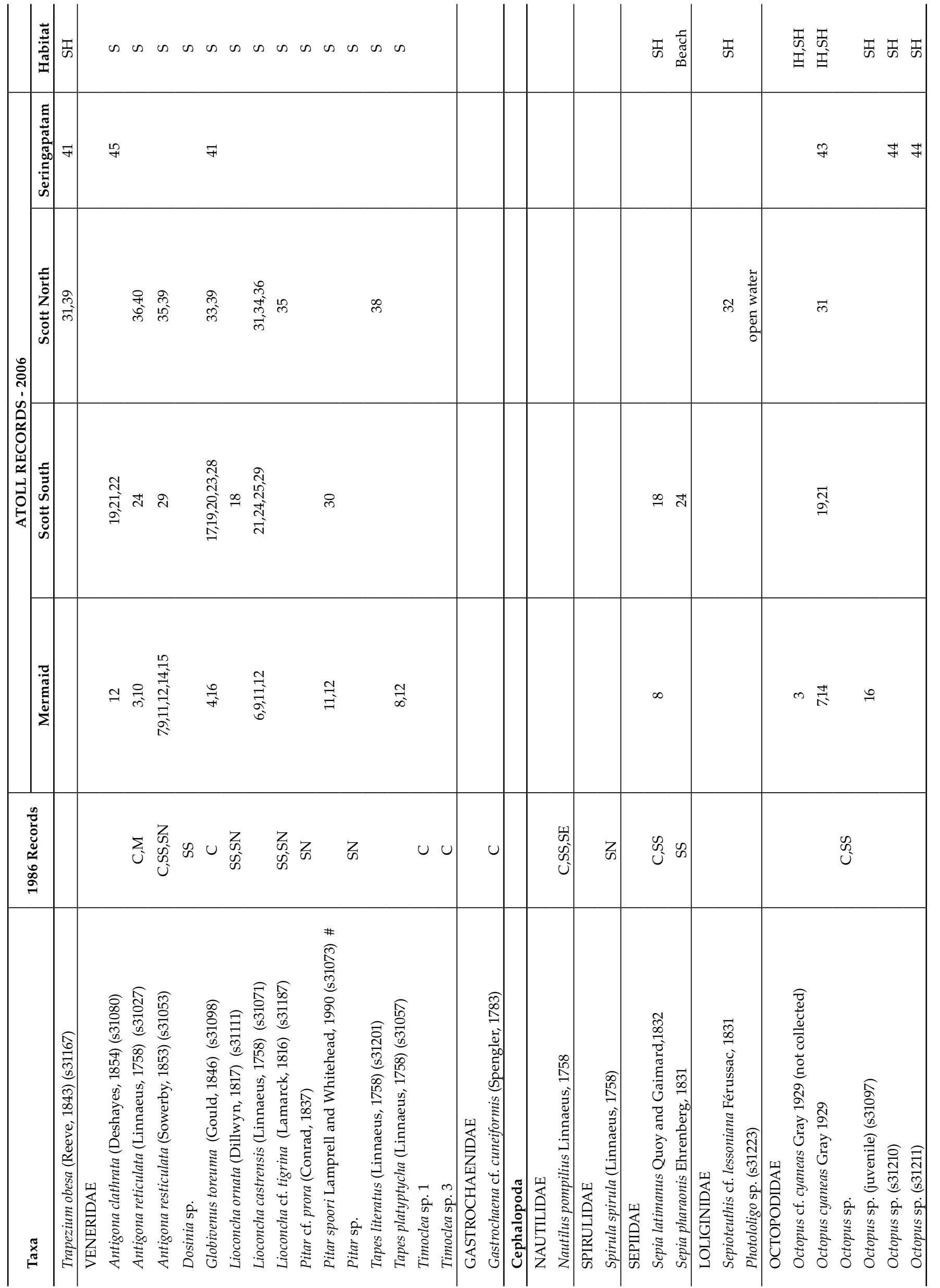




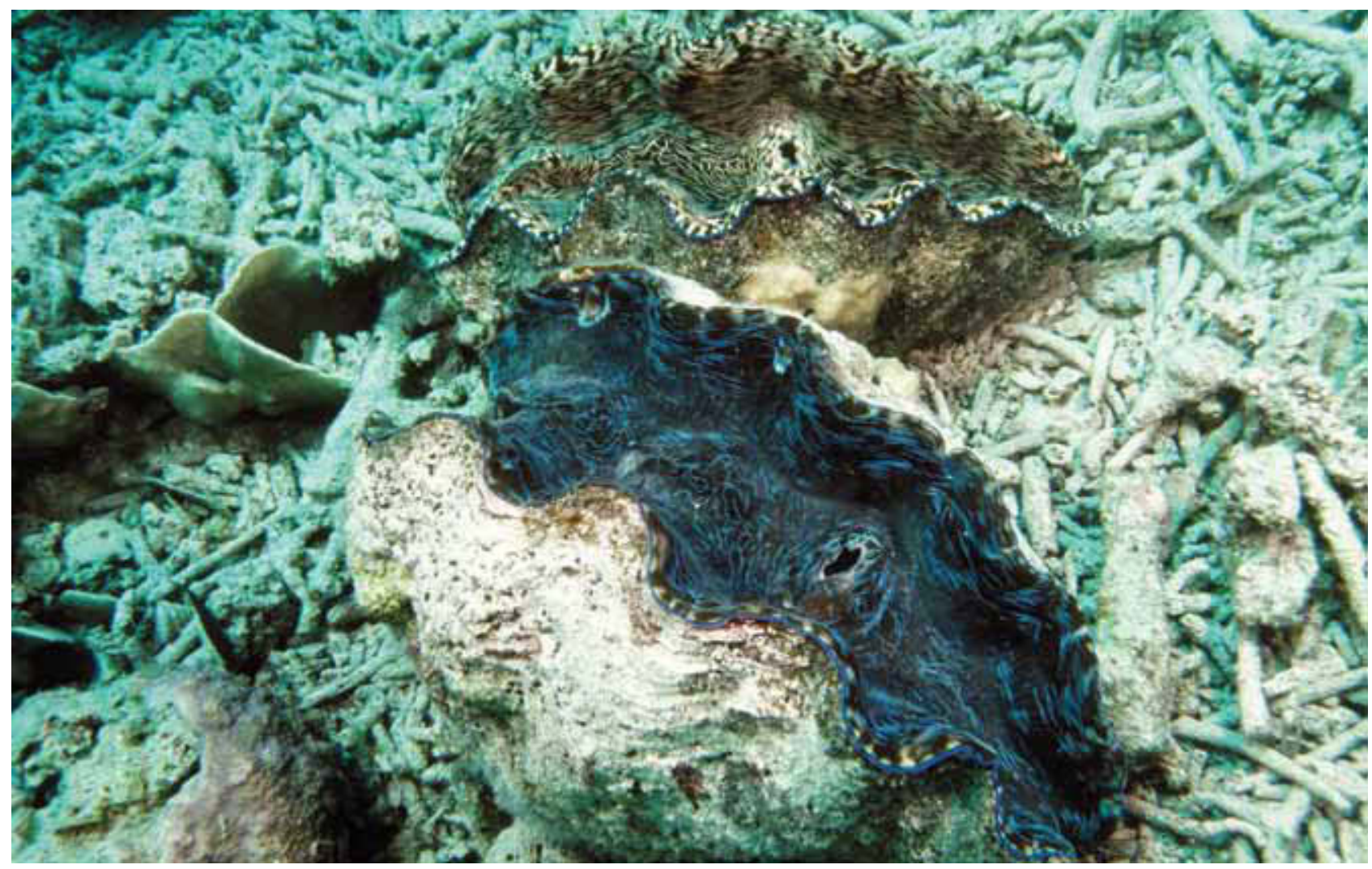

Above: Tridacna derasa (Röding, 1798) (Photo: Clay Bryce)

recorded comprising 280 gastropods, 101 bivalves, six cephalopds and two chitons. Molluscs identified during the 2006 survey totalled 339 species, comprising 261 gastropod, 70 bivalve, six cephalopod and two chiton species. Table 2 provides a summary of the total number of species recorded from each reef surveyed, arranged from south to north, together with the percentage of total species for each reef as represented by the various habitat divisions. Many species occurred in more than one habitat division and so were counted for each.

As indicated in Table 2, Subtidal-Hard (SH) and Sediment (S) are the two habitat types for which higher species percentages were consistently recorded. The percentages of species from those sites, when considered as totals from all reefs surveyed, far exceed those from the third dominant division, the Intertidal Hard (IH), and the remaining habitat divisions. These differences may be attributed to the greater number of habitat niches available to molluscs within the subtidal breakaway zones of the outer and inner reef slopes, which include the majority of $\mathrm{SH}$ and $\mathrm{S}$ sites. The difference in environmental conditions between the outer slope, with its vigorous wave action, and the inner reef edge, with a relatively quieter, crossplatform water flow, provides greater opportunities for habitat niche variability and nutrient retention.

In comparison, $\mathrm{IH}$ sites on the intertidal platforms are subjected to a water flow gradient across their width, diminishing from the wave-pounded outer slope to the relatively calm waters of the lagoon. Intertidal platforms are also topographically flat providing little protection for biota in the form of tide pools and coral slab debris. There is little sediment to be found on the platforms except in isolated back-reef areas. However, a limited molluscan fauna exists where there is a sufficient depth of sediment. Desiccation from low tide exposure, wide temperature fluctuations and increased predation of collectable species by Indonesian fishers also has an impact on diversity and abundance (pers. obs. C. Bryce).

Table 3 displays the average species count per station and the average species count at each major topographical reef feature (outer slope, intertidal platform and lagoon), with the number of stations in brackets. The molluscan faunas of South Scott and North Scott Reefs appear to be the most diverse with greater average species counts per station and across the three topographical reef features. In general, average species counts were higher at all reefs on the outer slope than at lagoon or intertidal platform habitats. A comparison of the combined outer slope and lagoon figures (equating to $\mathrm{SH}$ and $\mathrm{S}$ in Table 2) compared with the intertidal count $(\mathrm{IH})$; indicate a similar outcome, as expressed with Table 2.

Analysis using Multi-Dimensional Scaling (MDS) 
Table 2 Percentage of total molluscan species for each habitat division for the 2006 survey.

\begin{tabular}{|c|c|c|c|c|c|c|c|}
\hline \multirow{3}{*}{ Reef } & \multirow{3}{*}{ Total Species } & \multicolumn{6}{|c|}{ Habitat Divisions } \\
\hline & & IH & SH & $S$ & EP & EZ & $\mathbf{P}$ \\
\hline & & \multicolumn{6}{|c|}{$\%$ Species } \\
\hline Mermaid & 185 & 22.99 & 60.96 & 34.23 & 1.07 & 4.81 & 0.00 \\
\hline South Scott & 221 & 21.72 & 52.94 & 38.91 & 1.36 & 5.88 & 0.45 \\
\hline North Scott & 183 & 29.35 & 54.35 & 41.30 & 0.00 & 3.17 & 0.54 \\
\hline Seringapatam & 120 & 28.10 & 56.20 & 35.54 & 3.31 & 4.13 & 0.00 \\
\hline
\end{tabular}

Table 3 Reefs surveyed in 2006, with average species and number of stations (x).

\begin{tabular}{l|c|c|c|c}
\hline Reef & $\begin{array}{c}\text { Average species } \\
\text { per station }\end{array}$ & $\begin{array}{c}\text { Average species for } \\
\text { outer reef slope }\end{array}$ & $\begin{array}{c}\text { Average species for } \\
\text { intertidal platform }\end{array}$ & $\begin{array}{c}\text { Average species for } \\
\text { lagoon }\end{array}$ \\
\hline Mermaid & $34(16)$ & $37(5)$ & $37(1)$ & $33(8)$ \\
South Scott & $47(14)$ & $49(6)$ & $59(3)$ & $38(5)$ \\
North Scott & $43(10)$ & $51(3)$ & $44(3)$ & $39(3)$ \\
Seringapatam & $36(5)$ & $45(2)$ & $46(1)$ & $23(2)$ \\
\hline
\end{tabular}

of the molluscan biodiversity presence /absence data is presented in Figures 1 and 2 using the Bray Curtis Similarity Matrix. The data for the intertidal platform and channel stations were omitted to maintain a consistent sampling strategy for all stations.

The breakdowns of data in the MDS plot (Figure 1) supported by the dendrogram (Figure 2), clearly differentiate Mermaid Reef, $400 \mathrm{~km}$ to the south, from South and North Scott and Seringapatam Reefs.

At a finer scale the data for the lagoons and outer slopes, for all reefs, show a meaningful separation. There is also an organised spread of sampling points related to the prevailing environment from very exposed to very protected stations, progressing outward from the centre of the plot (Figure 1). To the left, the sampling points align with increasingly-exposed, high-energy environments (Stations 17 and 41) and to the right they align with increasingly protected, low energy, lagoonal sites (Stations 6, 7 and 43).

From the dendrogram (Figure 2), outlier stations are evident at Stations 1, 18 and 43. Station 1 at the eastern side of Mermaid Reef lagoon revealed a similarity with Stations 32 and 38 from North Scott lagoon, even though the distance between the two reefs is more than $400 \mathrm{kms}$. Examination of Table 1 revealed the inclusion of several common outer reef platform species, such as Drupa rubusidaeus, Vasum turbinellum, Conus miliaris, and Conus sponsalis at Station 1 to be a contributing factor. All four species are common on the outer reef platform. A comparison of the remaining Mermaid lagoonal reef-edge stations (Stations 6, 7, 8 and 11) indicated that the difference in intertidal platform width has an influence. At Station 1 the intertidal platform was narrow with a more uniform habitat across its entire width, which is favoured by these commonly-occurring species. This is not the case for the stations on the considerably wider western lagoon edge (Stations 6, 7 and 8), where deposited coralline sands dominate the inner half of the intertidal platform providing poor habitat for these same species. Station 11, although on the same narrow platform as Station 1, is subjected to a constant dusting of silt due to its proximity to the channel (pers. obs. C. Bryce).

Station 18 at South Scott Reef (Figures 1 and 2), appears to be intermediate between those of the lagoon and outer reef stations of Mermaid Reef. Work being undertaken by AIMS has revealed that the water influencing Station 18, between the western horn of South Scott Reef and Sandy Islet, is constantly mixed with oceanic water (Gilmore AIMS pers. comm.) This water mixing, combined with that location's habitat complexity, may have buffered the molluscan communities from the effects of elevated water temperatures, which had affected so much of South Scott Reef in 1998 and 2003. Mermaid Reef had also been affected at those times but to a lesser extent (Rees et al., 2003; Gilmore et al., 2007).

Figures 3 and 4 indicate the more common species of bivalves and gastropods respectively, expressed as the average number of individuals/50 $\mathrm{m}^{2}$.

Considerable variation is evident between the 


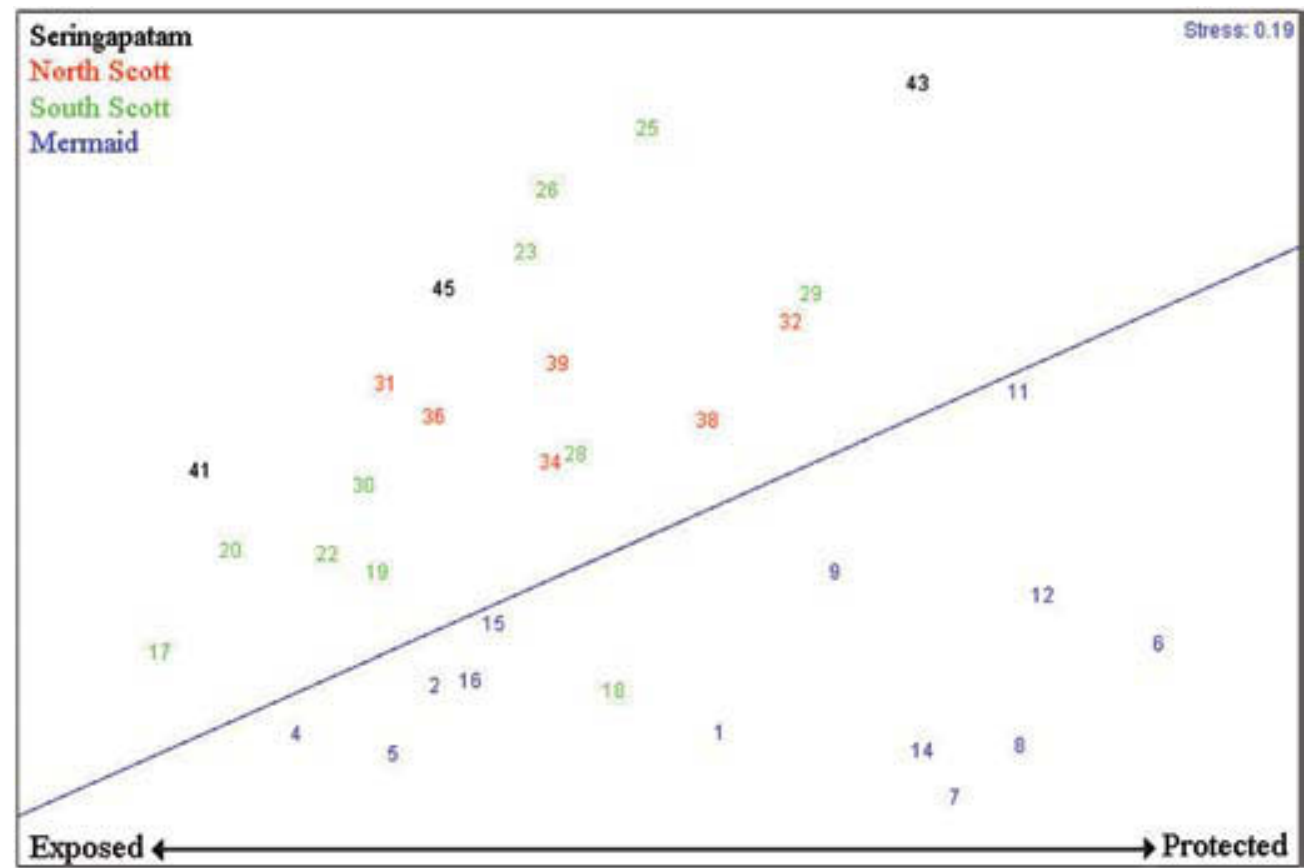

Figure 1 Multi-dimensional scaling ordination of molluscan presence / absence data for surveyed lagoon and outer slope stations.

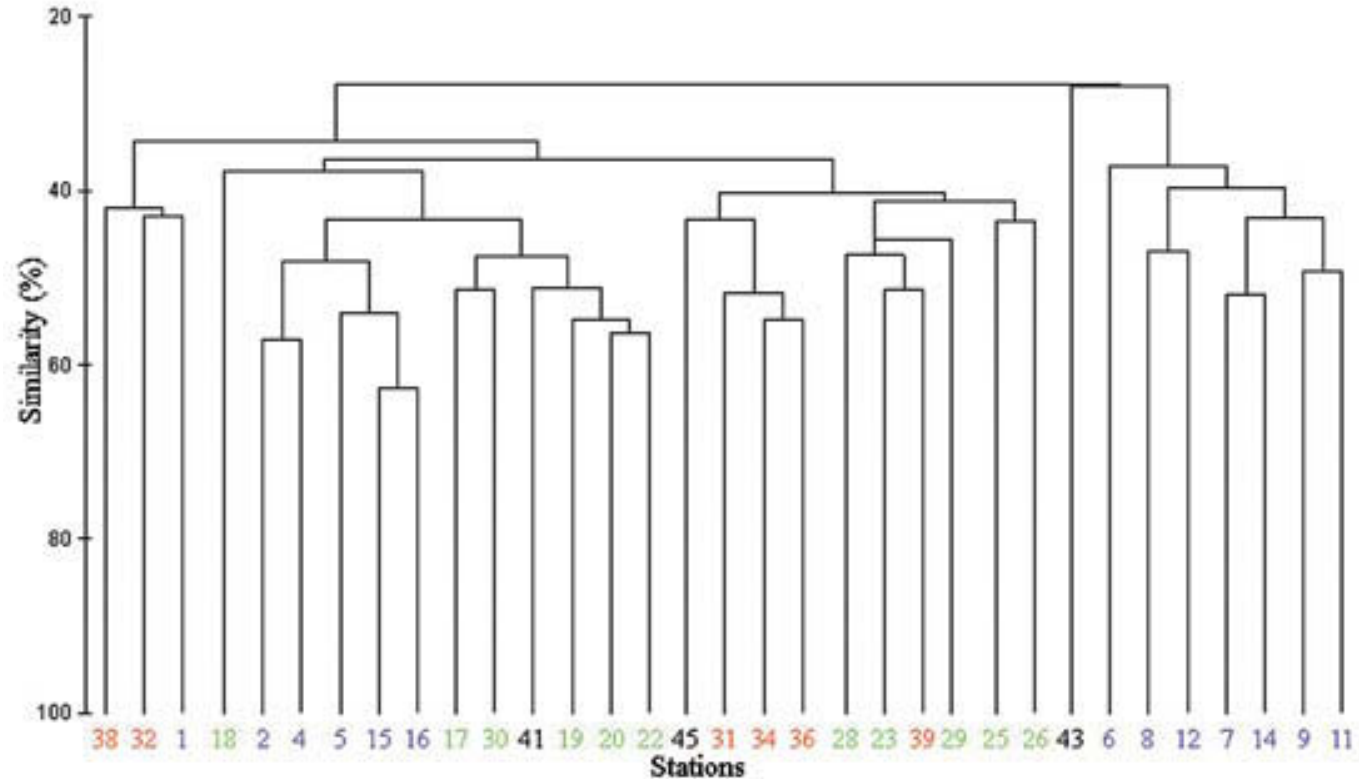

Figure 2 Dendrogram showing station similarity of molluscan presence/absence for lagoon and outer slope stations. 


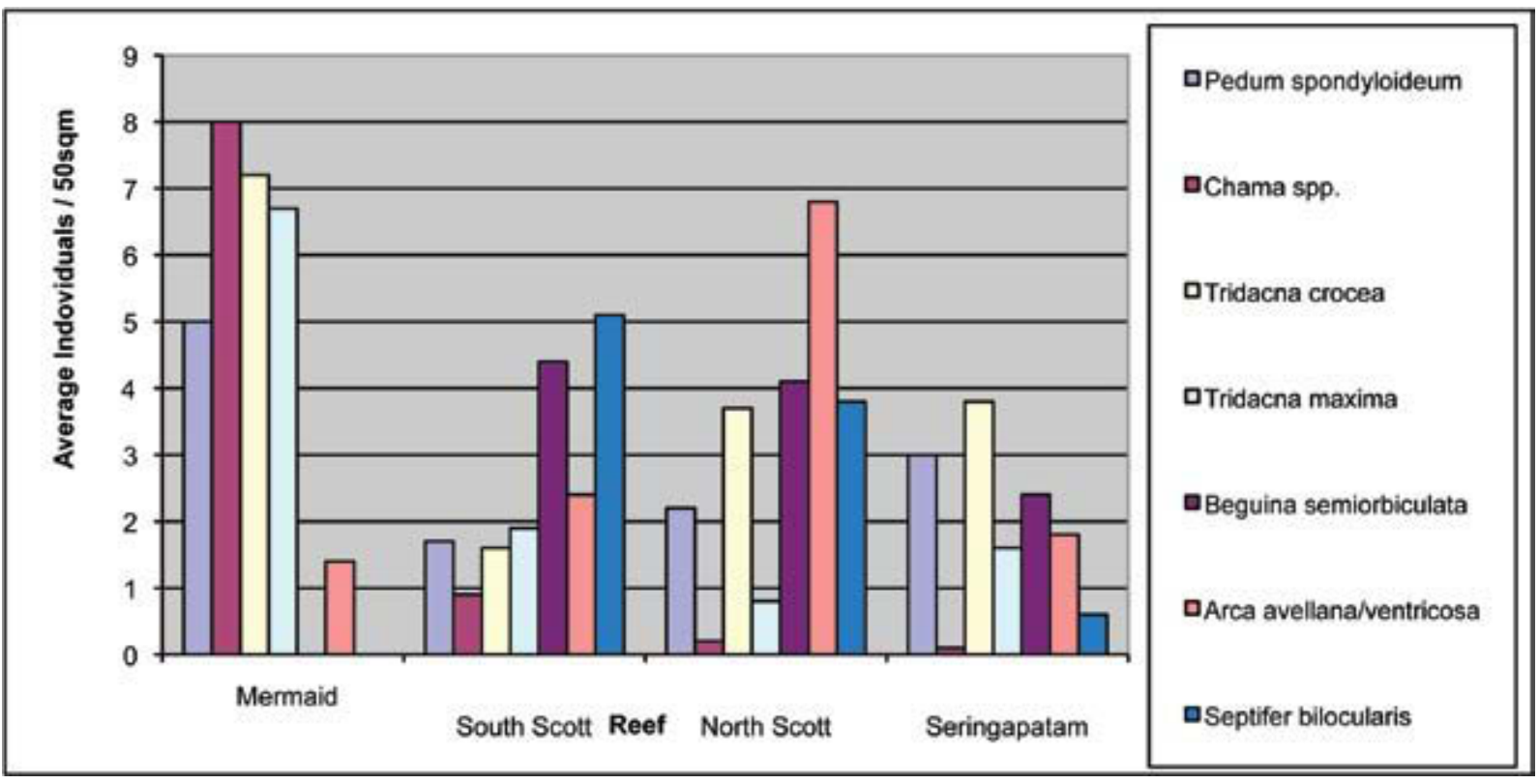

Figure 3 Average bivalve individuals / $50 \mathrm{~m} 2$

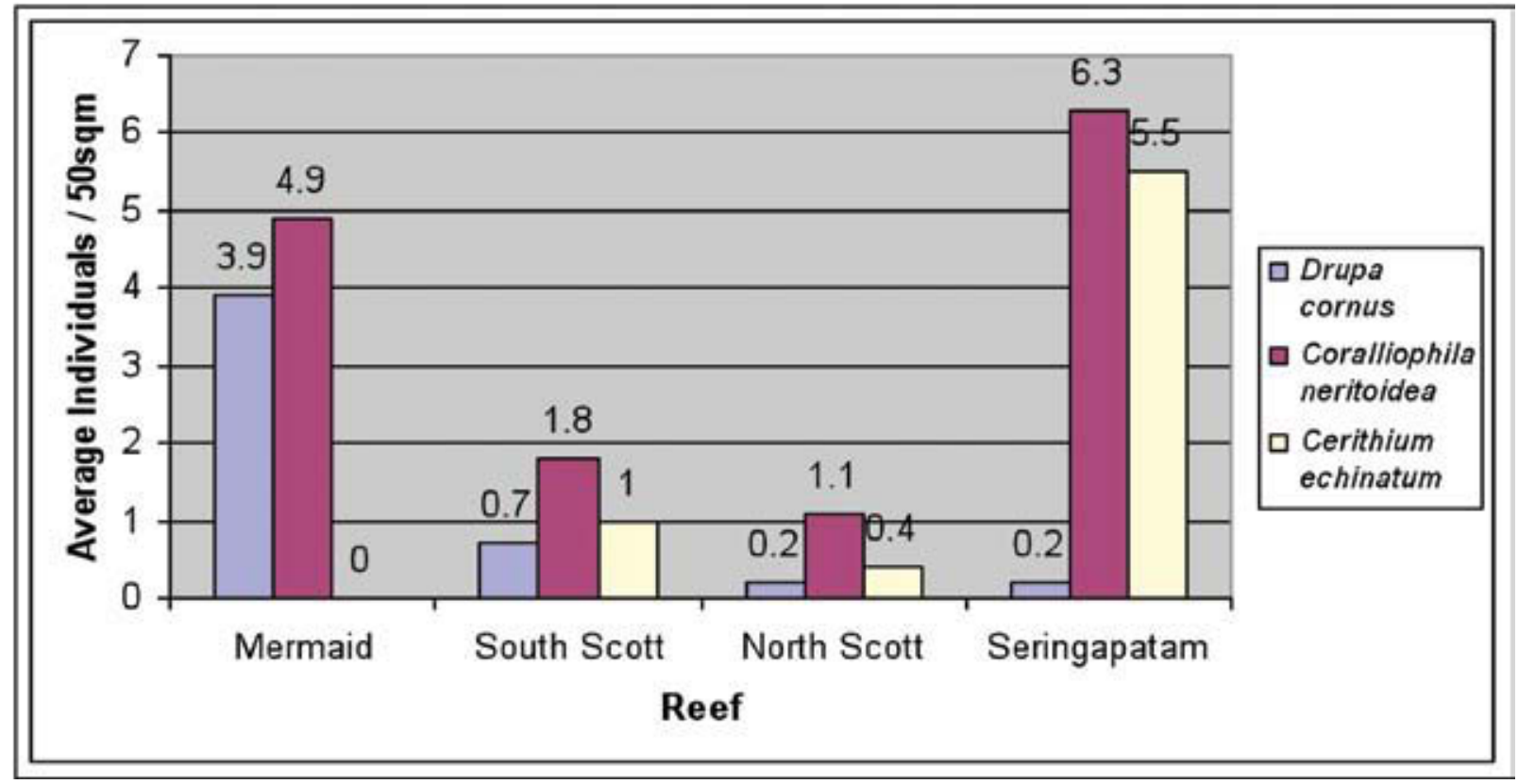

Figure 4 Average gastropod individuals / 50 sq. metres

density and makeup of the molluscan assemblages for North and South Scott Reefs and Seringapatam Reefs, when compared with those of Mermaid Reef. Of particular note is the lower numbers of the giant clam species, Tridacna maxima and Tridacna crocea, at North and South Scott Reefs and Seringapatam Reef. The densities of the other giant clam species, Tridacna gigas, Tridacna squamosa and Tridacna derasa, were too low for a meaningful comparison between reefs. These findings are consistent with the results reported by the senior author from a survey of the invertebrate marine resources of the shallow water habitats of North and South Scott Reefs undertaken in the first half of 2006 (Bryce, 2006).

The density of the coral nestling pectinid, Pedum spondyloideum, is also lower at Scott and Seringapatam Reefs compared with that at Mermaid Reef. The low numbers in this species at the more northerly reefs may be attributed to the decline in coral abundance due to bleaching and cyclonic activity (Rees et al., 2003; Gilmore et al., 2007).

The high densities of the bivalves, Beguina semiorbiculata, Septifer bilocularis and the Arca avellana / ventricosa species complex at North 


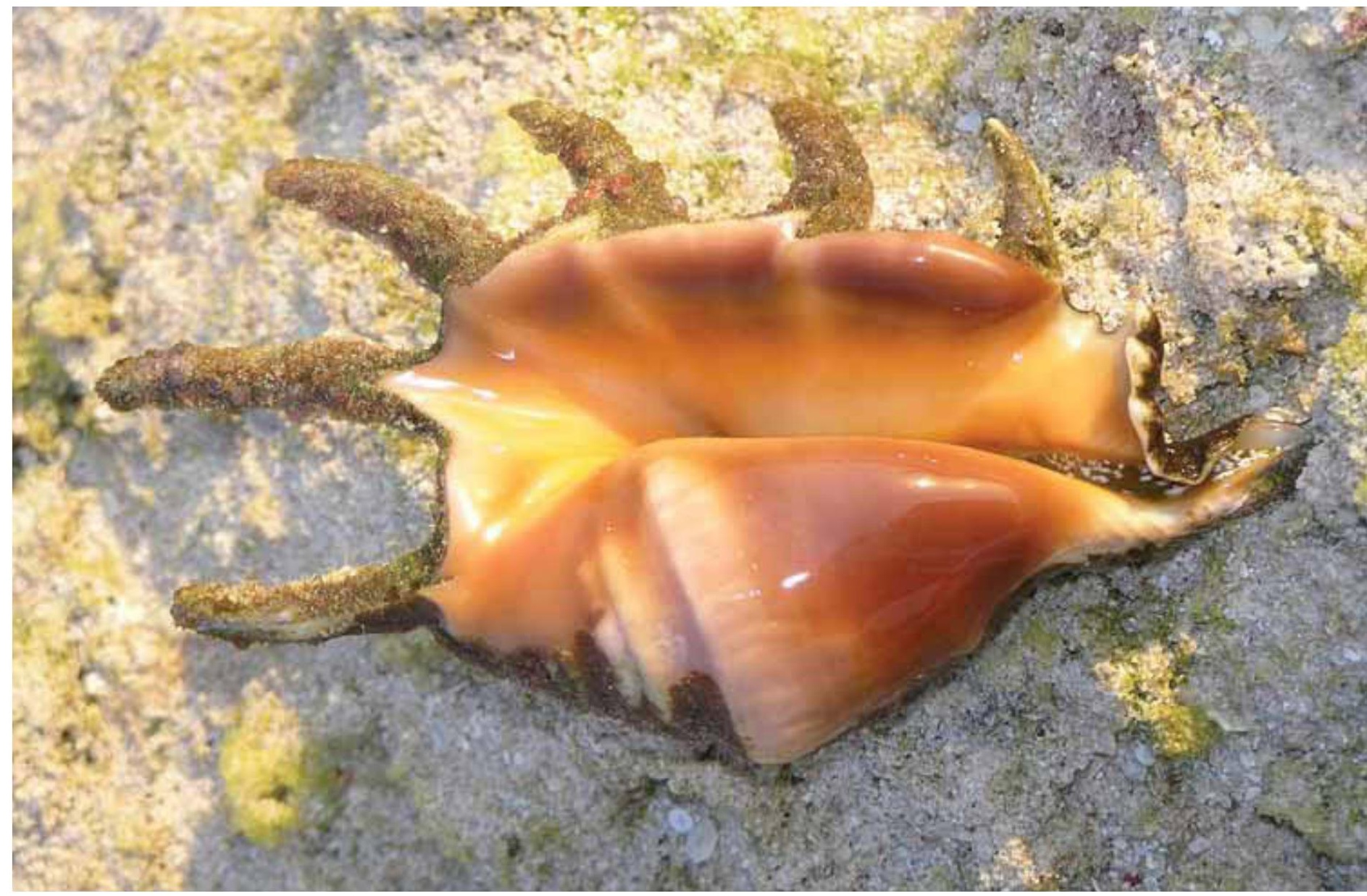

Above: Lambis lambis (Linnaeus, 1758) (Photo: Clay Bryce)

Scott Reef, and to a lesser extent at South Scott and Seringapatam Reefs, is intriguing. At some survey stations, high numbers of these species are associated with isolated massive coral colonies and it would appear that North Scott Reef has a greater number of such stations. Just as intriguing is the situation with Septifer bilocularis on Mermaid Reef. While this mussel species is common on the mainland coast and the more northern atolls, it was recorded from only a single station on Mermaid Reef and not from any of the replicated, quantitative transects. This situation could perhaps be due to the isolation of Mermaid Reef from the more "clumped" northern reefs closer to Indonesia, and hence from the northern larval-carrying currents. However, further work needs to be undertaken to fully comprehend the geographical distribution of this and other molluscan species. Some caution has had to be exercised with regard to both the qualitative and the quantitative data from Seringapatam as the reef was under-sampled, during this and all other surveys undertaken so far.

The most common gastropods encountered at Mermaid Reef were Coralliophila neritoidea and Drupella cornus (Figure 4). Both of these corallivorous species are dependant on live coral for survival. Neither species could be considered to be in plague proportions on this reef at this time. However, at North and South Scott Reefs and to a lesser extent at Seringapatam Reef, the low numbers may reflect the damage to coral stock from coral bleaching and subsequent cyclonic activity as described by Rees et al. (2003) and Gilmore et al. (2007).

Cerithium echinatum was moderately abundant at Scott (North and South) and Seringapatam Reefs during the 2006 survey, being recorded from $50 \%$ of transects. There were no records of the species from the quantitative transects at Mermaid Reef although the species was recorded, in low numbers, from $44 \%$ of the survey stations (Table1). The species does not appear to have been common during the 1980s. The WA Museum's 1986 survey report records the species from only a single station at Mermaid Reef and not at all on North or South Scott Reefs or Seringapatam Reef. However, Wilson (1985) recorded two specimens from Seringapatam Reef in 1978. Representatives of the family Cerithiidae, to which this species belongs, are generally gregarious detrital feeders consuming microalgae, bacteria and detrital matter (Wilson, 1993). With the decline of holothurians on 
Table 4 Number of stations sampled for Molluscs - 1986 publication and 2006 survey.

\begin{tabular}{l|c|c|c|c|c|c}
\hline & Clerke & Mermaid & Sth. Scott & Nth. Scott & Sering. & Totals \\
\hline 1986 publication & 20 & 2 & 12 & 11 & 2 & 47 \\
2006 survey & & 16 & 14 & 10 & 5 & 45 \\
\hline
\end{tabular}

Scott Reef (Bryce, 2006) it could be assumed that nutrient levels in the sediment have increased. With that in mind, it would seem possible that the rise in numbers of Cerithium echinatum may be related to such a nutrient increase. It should be noted that holothurian numbers and diversity on Mermaid Reef are far greater than on the northern atolls (Bryce and Marsh, this volume) and would, presumably, have some effect on controlling sediment nutrient levels and so might account for the lesser numbers of this gastropod species at Mermaid Reef.

The density spike for Cerithium echinatum on Seringapatam Reef (Figure 4) is unexplained. Two of the three Seringapatam stations recorded very high numbers giving an average density of 5.5 individuals per $50 \mathrm{~m}^{2}$. If more stations had been sampled, this average figure may have been reduced to levels more comparable with the other stations. It seems possible that the density of Cerithium echinatum may be increasing on all atolls, particularly on the northern reefs, until a new ecological balance is reached. Obviously, further work would be needed to clarify the matter.

There is also an apparent increase in abundance of Conus musicus and C. miles. Both species are vermivorous, preferring sandy pockets on intertidal and shallow subtidal reefs (Röckel, et al., 1995). In the WA Museum's 1986 published results, the former species was found at three stations, all from around Sandy Islet on South Scott Reef but the latter was recorded only from a single site on North Scott Reef (Wells and Slack-Smith, 1986). During the 2006 survey, both species were more widely encountered (Table 1) and, as with Cerithium echinatum, this may signify a population increase has occurred, perhaps due to habitat changes associated with a possible increase in levels of nutrient in the sediment.

\section{Comparative results - 1986 report and 2006 survey.}

Table 4 lists the number of stations surveyed at each reef for the 2006 survey compared with the previous WA Museum survey results, so providing an estimate of the differences in effort and collection opportunity across the reefs. The numbers of survey stations providing the 1986 and 2006 data sets are comparable, being 47 and 45 respectively.

By combining the stations for each reef system (i.e., Clerke and Mermaid, South and North Scott, and Seringapatam) and comparing them for both the 1986 publication results and the present survey, a clearer indication of collecting effort was determined (Figure 5). For example, 20 stations were sampled in the data published in 1986 for Clerke Reef with only two stations at Mermaid Reef - giving a total of 22 stations for the reef system. The third atoll of the system, Imperieuse Reef, was not surveyed in 1986. When this figure (22 stations)
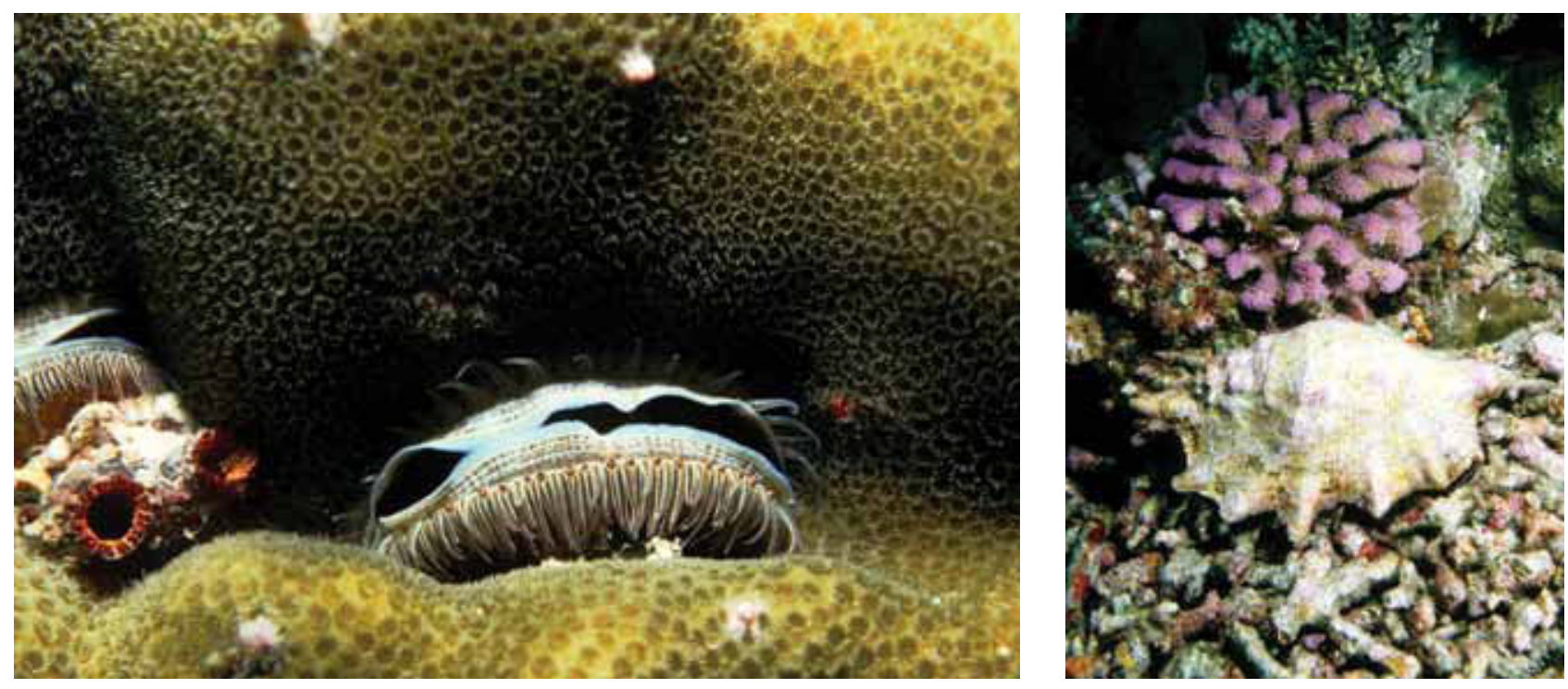

Left: Pedum spondyloideum (Gmelin, 1791); Right: Lambis truncata (Humphrey, 1786) (Photos: Clay Bryce) 


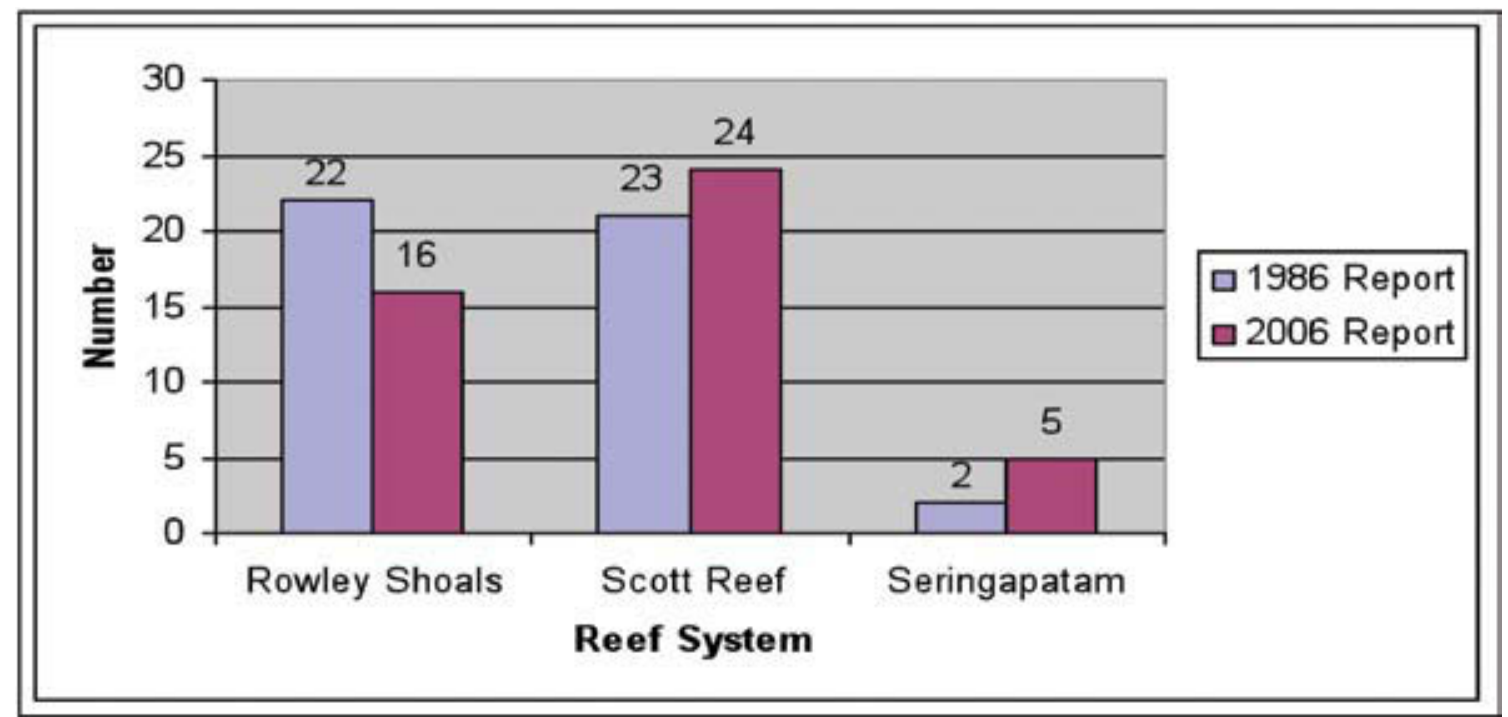

Figure 5 Comparison of the number of stations between reef systems for 1986 and 2006 reports.

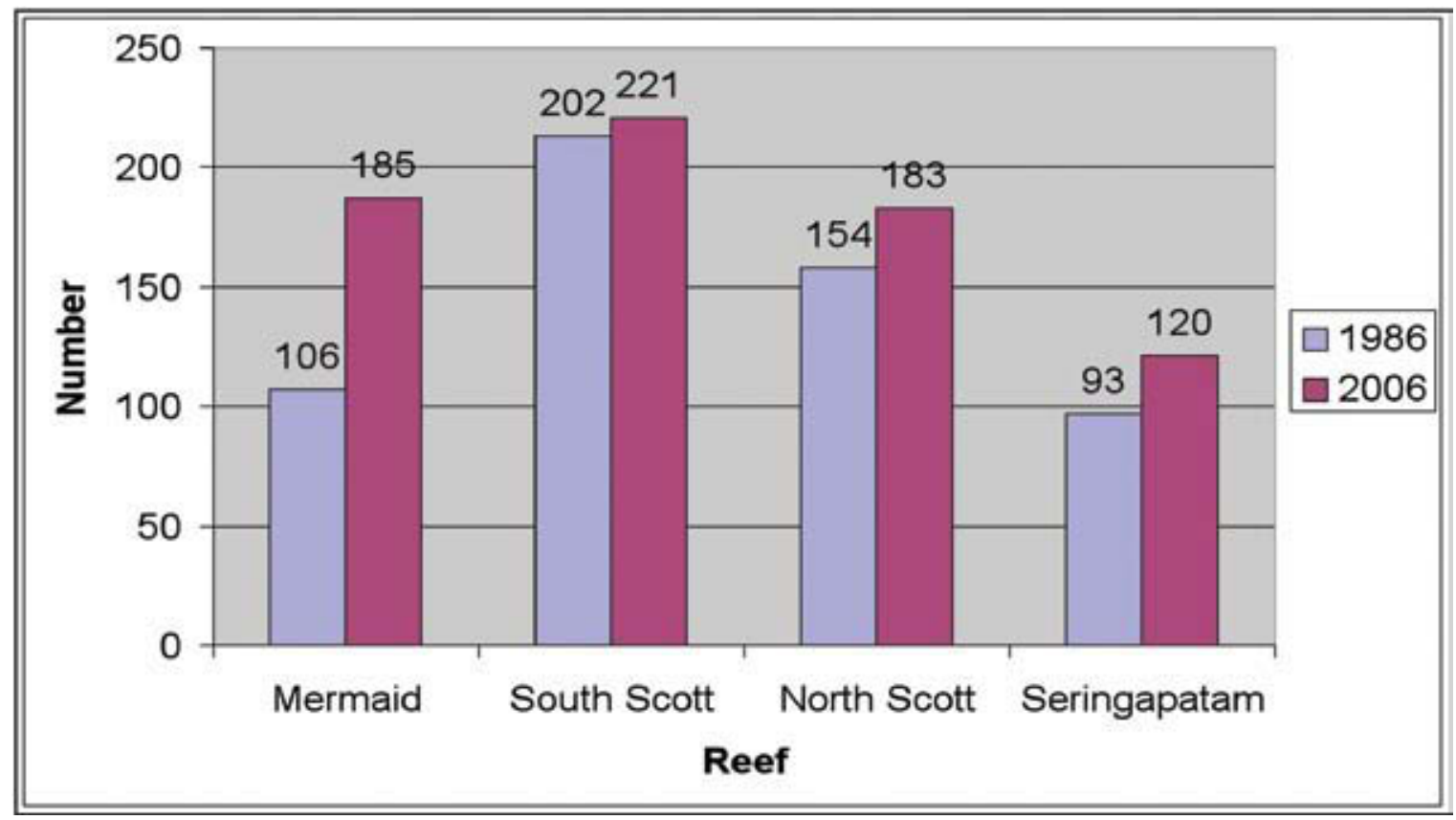

Figure 6 Comparative total species counts for Mermaid, South Scott, North Scott and Seringapatam Reefs for 1986 publication results and 2006 surveys.

is compared to the 2006 Rowley Shoals count (16 stations), the comparison can be seen to be more meaningful.

A comparison of total molluscan species recorded for all reefs during this survey and for those published in 1986 is provided in Figure 6 . Slightly more species were recorded in the 2006 survey, which may be due to differing collecting methodologies and advances in taxonomy.

The Venn diagram (Figure 7) portrays the distribution of all 479 species across three reef systems for both the 1986 published results and the 2006 survey, combined.

Scott Reef (North and South), with its greater habitat diversity, had the greater species total (372) and also that of reef-confined species (121). The lower total of species recorded for Seringapatam Reef (173) would seem to be due to a lower collecting effort, yet it still displayed a modest species affinity with its near neighbour, Scott Reef (North and South), sharing 27 species. Rowley 
Table 5 Comparison of results of this and similar surveys of northwest Australian areas (listed from north to south)

\begin{tabular}{|c|c|c|c|c|}
\hline \multirow[b]{2}{*}{ Surveyed Locality } & \multicolumn{2}{|c|}{ Indication of Effort } & \multirow{2}{*}{$\begin{array}{c}\text { Total } \\
\text { species }\end{array}$} & \multirow[b]{2}{*}{ Source } \\
\hline & $\begin{array}{l}\text { Number of } \\
\text { Collectors }\end{array}$ & Survey days & & \\
\hline Christmas I. & 3 & $\begin{array}{c}12 \\
\text { (36 person days) }\end{array}$ & 313 & Wells \& Slack-Smith, 1988 \\
\hline Ashmore \& Cartier Rf. & 2 & $\begin{array}{c}11 \\
\text { (22 person days) }\end{array}$ & 433 & Wells, 1993 \\
\hline Cocos (Keeling) Is. & 2 & $\begin{array}{c}20 \\
(40 \text { person days })\end{array}$ & 380 & Wells, 1994 \\
\hline Mermaid, Scott \& Seringapatam Reefs & 2 & $\begin{array}{c}16 \\
\text { (32 person days) }\end{array}$ & 339 & This survey \\
\hline Mermaid, Scott \& Seringapatam Reefs & 2 & $\begin{array}{c}11 \\
\text { (22 person days) }\end{array}$ & 324 & Wells \& Slack-Smith, 1986 \\
\hline Central Kimberley & 1 & $\begin{array}{c}13 \\
\text { (13 person days) }\end{array}$ & 292 & Bryce, 1997 \\
\hline Southern Kimberley & 2 & $\begin{array}{c}13 \\
\text { (26 person days) }\end{array}$ & 232 & Wells \& Bryce, 1995 \\
\hline Dampier Arch. & 2 & $\begin{array}{c}26 \\
\text { (52 person days) }\end{array}$ & 695 & Slack-Smith \& Bryce, 2004 \\
\hline Montebello Is. & 3 & $\begin{array}{c}17 \\
\text { (51 person days) }\end{array}$ & 633 & Wells, Slack-Smith \& Bryce, 1993 \\
\hline
\end{tabular}

Shoals and Scott Reef (North and South) share 100 species but still portray considerable species exclusivity with 85 and 121 species respectively. The three reefs have 124 species in common, with a reduction in overall species diversity from Scott Reef to Mermaid Reef. These figures appear to demonstrate the influence of the Indian Ocean Through-Flow current regime and the effects of inter and intra-reef system recruitment.

Table 5 compares the molluscs recorded from the 2006 survey with those of similar surveys undertaken by the WA Museum at other localities, including an indication of effort. Care should be taken in the interpretation of this table regarding the figures associated with surveys of the nearby Kimberley coast. Despite the greater habitat diversity of the Kimberley coast, the figures give a lower species count than for any of the surveyed oceanic locations. This is probably due to a bias towards the surveying of only intertidal platforms, mangals and general shoreline habitats, and a surveying of only a very small number of subtidal stations. Further surveying of Kimberley subtidal stations would, undoubtedly, increase the mainland-coast species count appreciably.

\section{New molluscan records.}

The discovery of the gastropod mollusc, Marchia martinetana (Röding, 1798) (Figure 8a) at North Scott Reef is a new record for Australia. New records for the Western Australian fauna are the columbellid gastropod, Euplica deshayesii (Crosse, 1859) (Figure $8 \mathrm{~b})$, the nudibranch, Notodoris serenae Gosliner and Behrens, 1997 (Figure 8c) and the lucinid bivalve Monitilora simplex (Reeve, 1850) (Figure 8d). Also of note is the venerid bivalve, Pitar spoori Lamprell and Whitehead, 1990 (Figure 8e). This species had previously been recorded in Western Australia only from Hibernia Reef (Willan, 2005).

\section{CONCLUSIONS:}

The molluscan fauna of the surveyed atolls is typical of Indo-West Pacific offshore, oceanic coral reefs (Wells \& Slack-Smith, 1986; Willan, 2005). From Table 1 it can be seen that the fauna has a greater affinity with that of the Indonesian Archipelago than with the Western Australian mainland. As such, these reefs are considered to represent a unique habitat of great conservation value.

The inclusion of replicated transects into a molluscan collecting regime has added valuable quantitative information by providing an indication of average molluscan density. The very act of swimming a transect tends to focus researchers' attention along a continuous band of substrate. This band is actually a defined slice through an otherwise borderless station area, thus providing for ongoing monitoring opportunities within a more defined area. Planned deviations from the transect and searching areas adjacent to the 

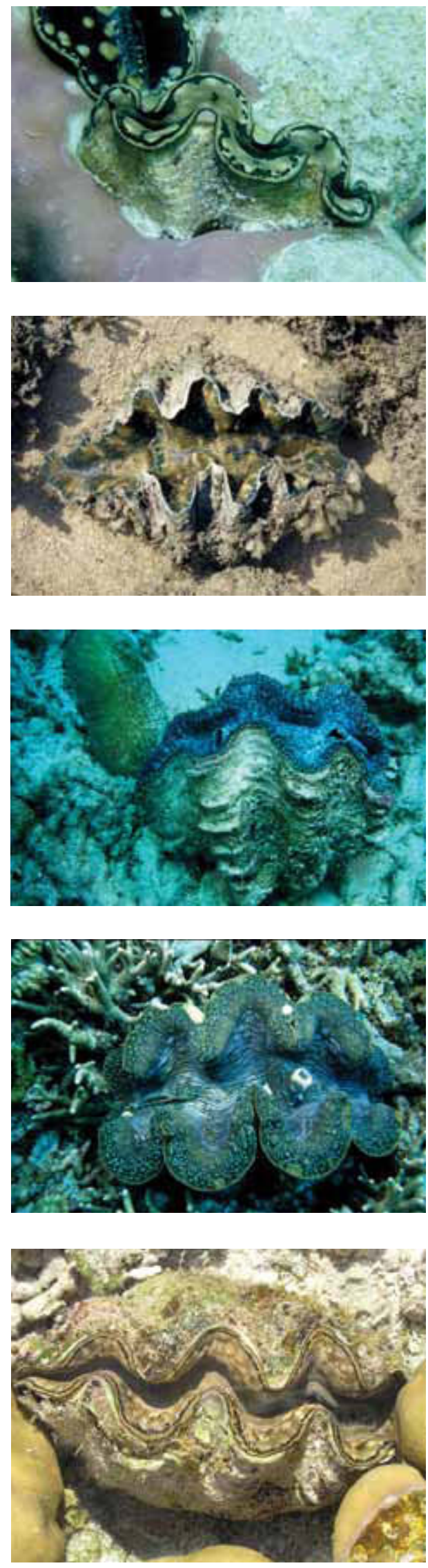

From top: Tridacna crocea Lamarck, 1819; Hippopus hippopus (Linnaeus, 1758); Tridacna squamosa Lamarck, 1819; Tridacna gigas (Linnaeus, 1758); Tridacna maxima (Röding, 1798). (Photos: Clay Bryce)

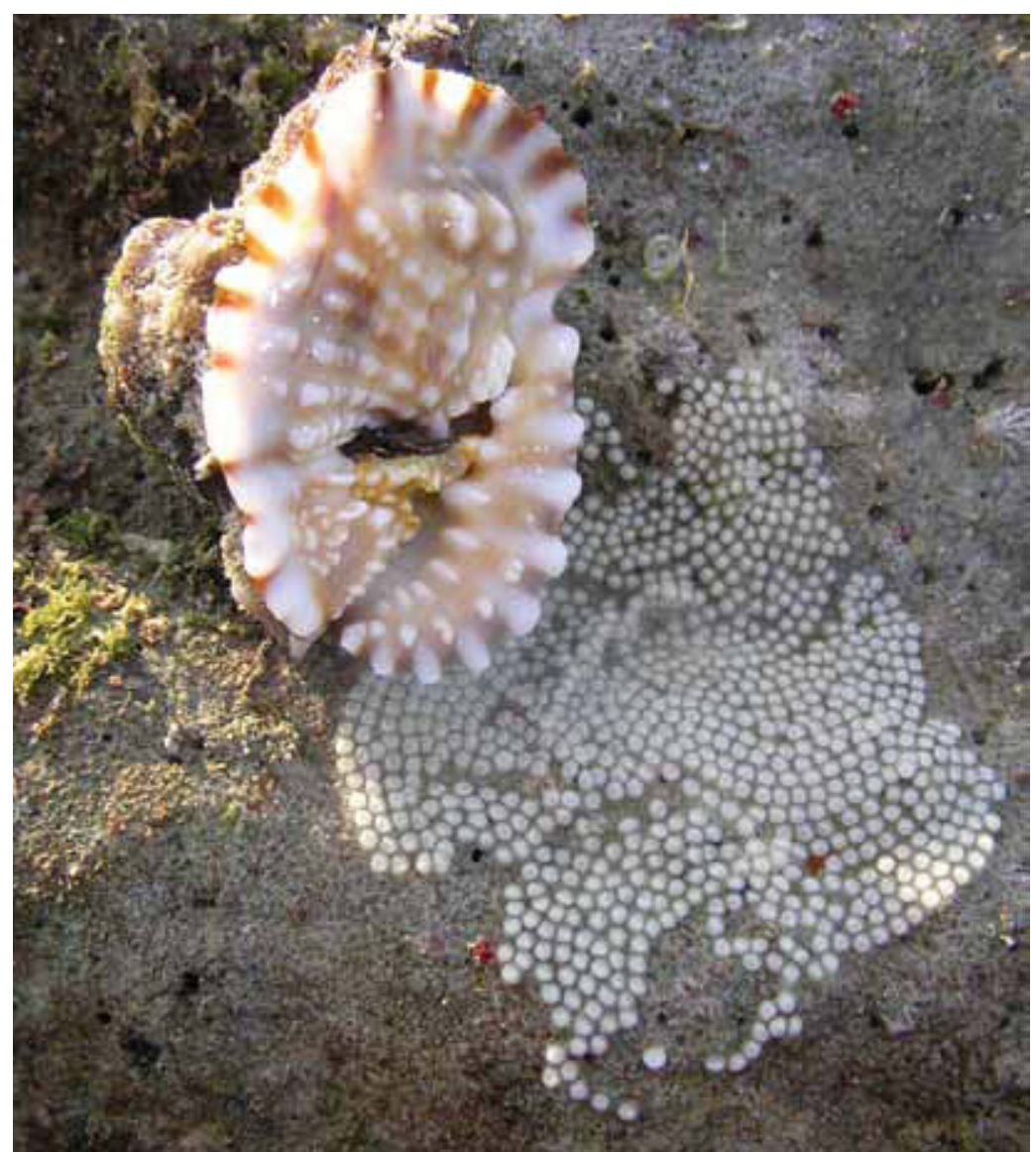

Above: Distorsio anus (Linnaeus, 1758) with eggs. (Photo: Clay Bryce)

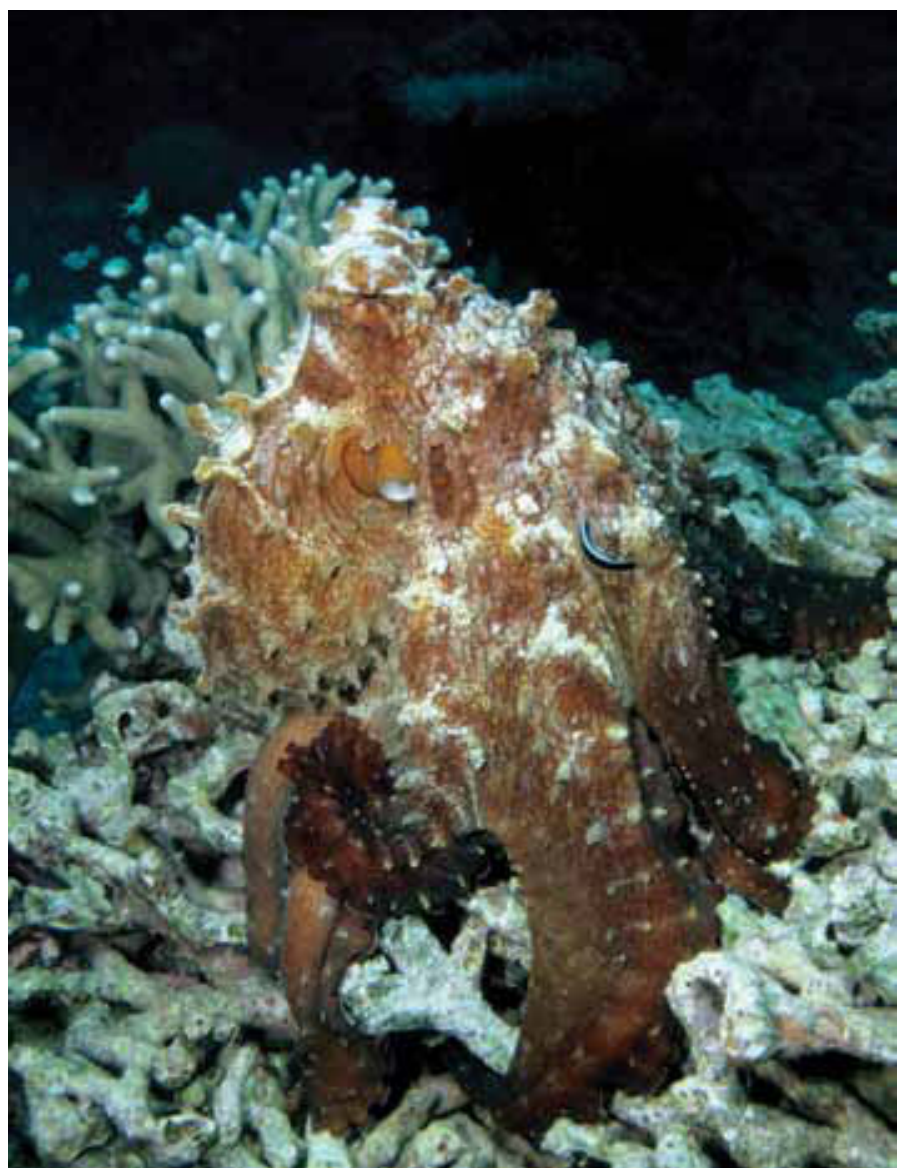

Above: Octopus cyanea Gray, 1849 (Photo: Clay Bryce) 


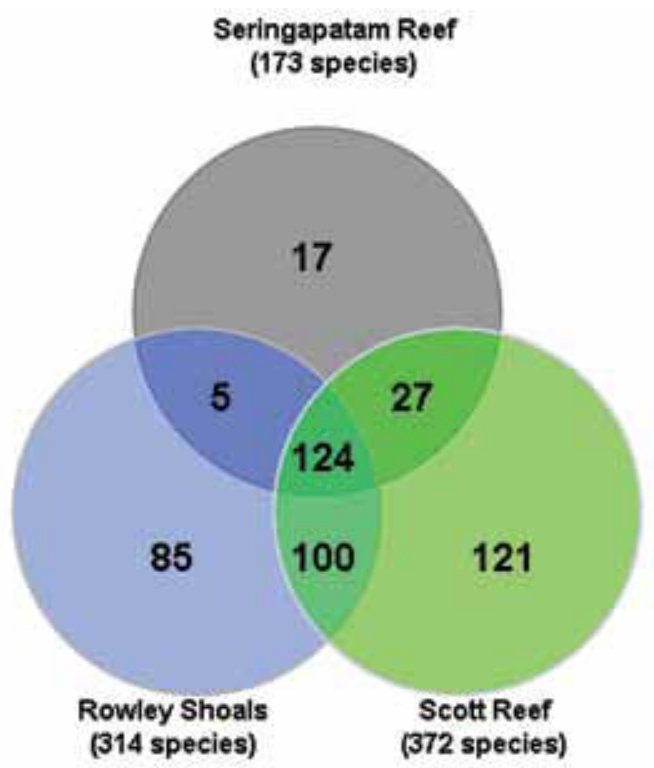

Figure 7 Venn Diagram showing species distributions at the Rowley Shoals, Scott Reef and Seringapatam Reef systems from the 1986 published report and this 2006 survey combined ( $\mathrm{n}=479$ species).

transect did allow for the amassing of qualitative species records. This is evidenced by examination of the species collected during this survey when compared to other surveys (Table 4).

The results of the 2006 survey yielded a total of 339 species of macromolluscs from Mermaid, Scott and Seringapatam Reefs but is not a complete inventory of the molluscan fauna as it does not include the poorly known and highly speciose micromolluscan fauna or faunal records housed in the collections of the WA Museum and of other museums in Australia and elsewhere (Table 4).

The relative diversity and number of marine habitats at these atolls influences their overall molluscan species diversity. South Scott Reef, with its large size, north-facing open lagoon, deep lagoonal waters (not sampled) and fractured back reef edge, provided a greater variety of habitats than the other atolls. However, unregulated fishing, cyclonic activity and recent warm water events leading to coral bleaching appear to have played an important part in reducing molluscan abundance and, to some extent, molluscan diversity on this reef. North Scott and Seringapatam Reefs have also suffered the same environmental and fishing pressures as South Scott Reef but appear to have the added constraint of reduced habitat diversity. This is due to their small size, annular shape and a reduced flushing regime. Mermaid Reef, $400 \mathrm{~km}$ to the south, mirrors North Scott and Seringapatam Reefs in shape and dimensions but apparently was little affected by high water temperatures (Gilmore et al., 2007) or fishing pressure due to its protected status.

All of these atolls, with the exception of Mermaid
Reef, have severely depleted populations of giant clams and of Tectus niloticus in both the shallow (Bryce, 2006) and the deeper waters of regions covered in this paper. This was attributed to the effects of environmental pressures and unregulated fishing practices.

The apparent increase in abundance of Cerithium echinatum, Conus miliaris and Conus musicus since the WA Museum's 1986 report may be attributed to these species having taken advantage of habitat changes due to an increase in nutrient-rich habitats possibly caused by the depletion of holothurian stocks (Bryce, 2006) across all reefs, except Mermaid Reef.

\section{ACKNOWLEDGEMENTS}

The authors would like to thanks the crew of the charter vessel Kimberley Quest for their assistance during the expedition. Ceri Morgan of Woodside Energy Ltd. provided valuable pre-trip assistance. Dr. Enrico Schwabe, Glad Hansen, Hugh Morrison and Shirley Slack-Smith provided invaluable help with identifications. Constructive manuscript advice from Dr. Barry Wilson, Dr. Richard Willan and Shirley Slack-Smith is greatly appreciated.

\section{REFERENCES}

Beesley, P.L., Ross, G.J.B. and Wells, A. (eds) (1998). Mollusca: The Southern Synthesis. Fauna of Australia. Melbourne: CSIRO Publishing Vol. 5, Parts A and B.

Berry, P.F. (ed.) (1986). Faunal Surveys of the Rowley Shoals, Scott Reef, and Seringapatam Reef, Northwestern Australia. Records of the Western Australian Museum Supplement. 25: 1-106. 
a)
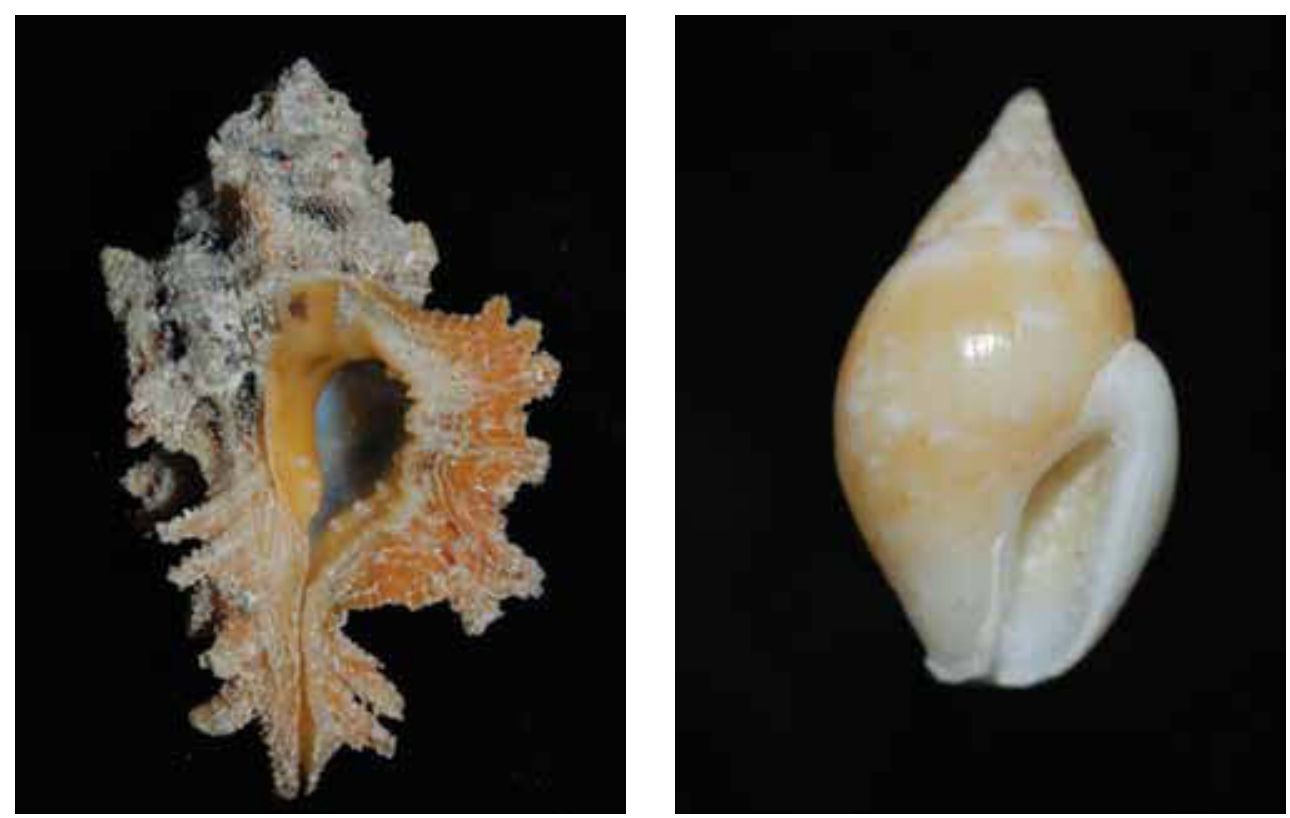

b) d)

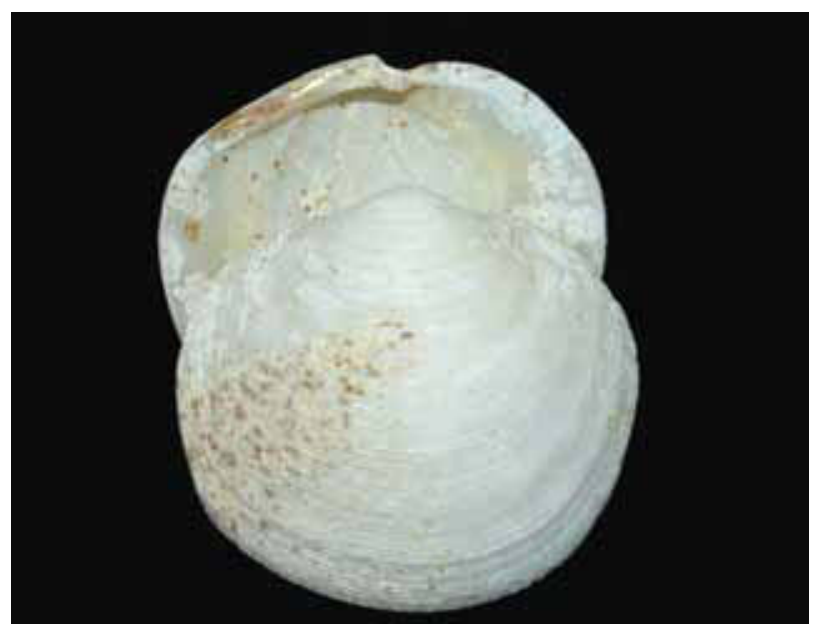

c)

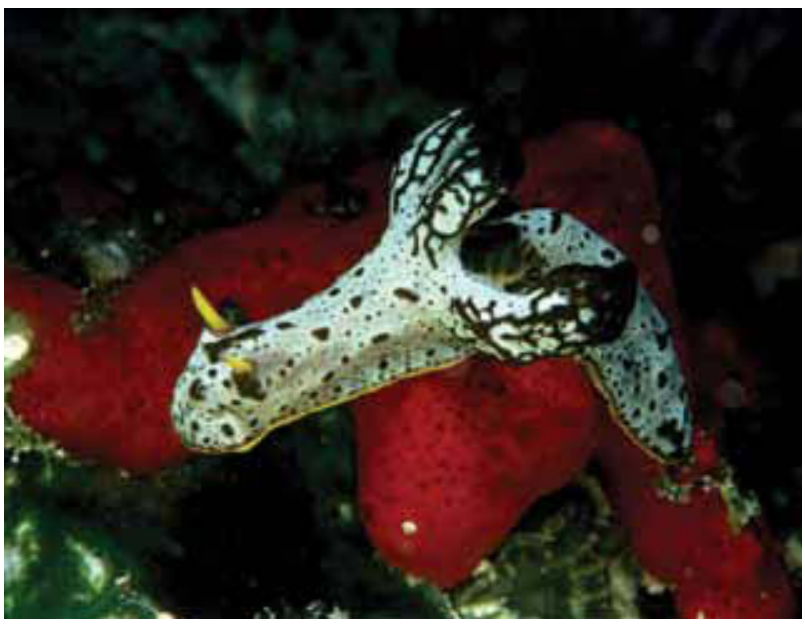

e)

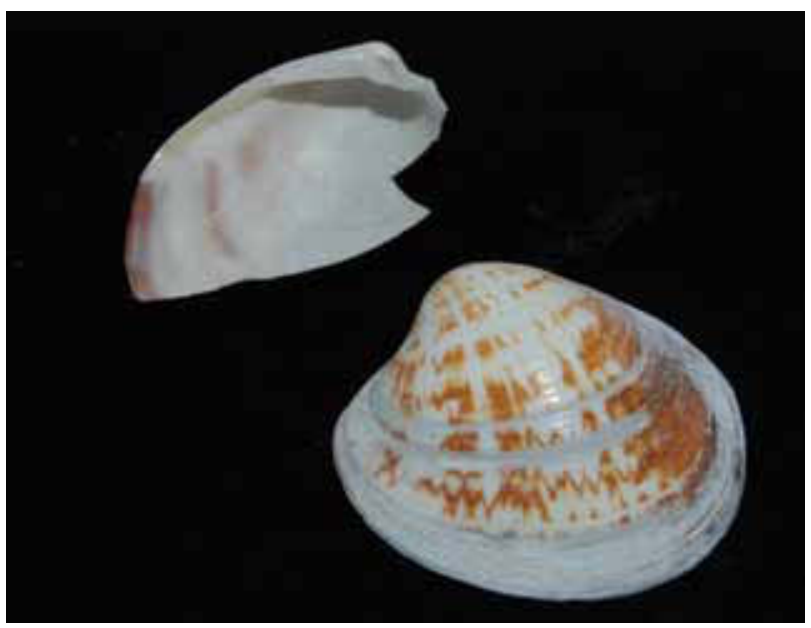

Figure 8 a: Marchia martinetana (Röding, 1798); b: Euplica deshayesii (Crosse, 1859); c: Notodoris serenae Gosliner and Behrens, 1997; d: Monitilora simplex (Reeve, 1850); e: Pitar spoori Lamprell and Whitehead, 1990. 
Berry, P.F. (ed.) (1993). Marine faunal surveys of Ashmore Reef and Cartier Island, north-western Australia. Records of the Western Australian Museum Supplement. 44: 1-91.

Bryce, C.W. (1997). Molluscs. In D.I. Walker (ed.), Marine Biological Survey of the Central Kimberley Coast, Western Australia: 46-57. National Estate Grant Program. Unpublished Report

Bryce, C.W. (2006). Invertebrate Marine Resources of Scott and Seringapatam Reefs (and Browse Island). .Unpublished report .

Röckel, D.R., Korn, W., Kohn, A.J. (1995). Manual of the Living Conidae. Volume 1: Indo-Pacific Region. Verlag Christa Hemmen. 517pp.

Gilmore, J., Cheal, A., Smith, L., Underwood, J., Meekan, M., Fitzgibbon, B. and Rees, M. (2007). Data compilation and analysis for Rowley Shoals: Mermaid Imperieuse and Clerke Reefs. Prepared for Department of the Environment and Water Resources. Unpublished Report.

Slack-Smith, S.M. and Bryce, C.W. (1996). Molluscs. In Hutchins, J.B., Slack-Smith, S.M., Bryce, C.W., Morrison, S.M. and Hewitt, M.A. (eds), Marine Biological Survey of the Muiron Islands and the Eastern Shore of Exmouth Gulf, Western Australia. Ocean Rescue 2000 Program. 64-101.

Slack-Smith, S.M. and Bryce, C.W. (2004). A survey of the benthic molluscs of the Dampier Archipelago, Western Australia. In Jones, D.S. (ed.), Marine Biodiversity of the Dampier Archipelago Western Australia 1998. Records of the Western Australian Museum Supplement. 66: 221-245.

Rees, M., Colquhoun, J., Smith, L. and Heywood, A. AIMS. (2003). Survey of Trochus, holothurian, giant clams and the coral communities at Ashmore Reef, Cartier Reef and Mermaid Reef, Northwestern Australia. Australian Institute of Marine Sciences Report.

Walker, D.I., Wells, F.E. and Hanley, J.R. (eds) (1996). Marine Biological Survey of the eastern Kimberley, Western Australia. University of Western Australia, Western Australian Museum, Northern Territory Museum and Art Gallery. Unpublished Report.

Wells, F.E. (2000). Molluscs of Christmas Island. In Berry,
P.F. (ed.), Survey of the marine fauna of Cocos (Keeling) Islands, Indian Ocean:46-68. Western Australian Museum Unpublished Report.

Wells, F.E. 1993. Molluscs of Ashmore Reef and Cartier Island. In Berry, P.F. (ed.) Marine faunal surveys of Ashmore Reef and Cartier Island, north-western Australia. Records of the Western Australian Museum Supplement. 44: 25-46.

Wells, F.W., and Bryce, C.W. 1995. Molluscs. In Wells, F.E. and Hanley, J.R.(eds), Marine Biological Survey of the Southern Kimberley, Western Australia.101-117. Unpublished Report.

Wells, F.E. and Bryce, C.W. (1997). A preliminary checklist of the marine macromolluscs of the Houtman Abrolhos, Western Australia. pp. 363383. In Wells, F.E. (ed.), Proceedings of the Seventh International Marine Biological Workshop: The Marine Flora and Fauna of the Houtman Abrolhos Islands, Western Australia. Western Australian Museum, Perth.

Wells, F.E. and Slack-Smith, S.M. (1986). Part IV. Molluscs. In Berry, P.F. (ed.), Faunal Surveys of the Rowley Shoals, Scott Reef, and Seringapatam Reef, Northwestern Australia. Records of the Western Australian Museum Supplement. 25: 41-57.

Wells, F.E., Slack-Smith, S.M. and Bryce, C.W. (2000). Molluscs of Christmas Island. In Berry, P.F. and Wells, F.E. (eds.), Survey of the marine fauna of the Montebello Islands, Western Australia and Christmas Island, Indian Ocean. Records of the Western Australian Museum Supplement 59: 29-46.

Willan, R.C. (2005). The molluscan fauna from the emergent reefs of the northernmost Sahul Shelf, Timor Sea - Ashmore, Cartier and Hibernia Reefs; biodiversity and zoogeography. The Beagle, Records of the Museums and Art Gallery of the Northern Territory 2005, Supplement 1: 51-81.

Wilson, B.R. (1985). Notes on a brief visit to Seringapatam Atoll, North West Shelf, Australia. Atoll Research Bulletin 292: 83-100.

Wilson, B.R. (1993) Australian Marine Shells. Prosobranch gastropods. Volume 1. Odyssey Publishing. Perth, Western Australia. 